\title{
Impact of being a West Virginia State FFA President on Career and Personal Accomplishments as Perceived by Past State FFA Presidents 1955 to 2005
}

Jada M. Bennett

Follow this and additional works at: https://researchrepository.wvu.edu/etd

\section{Recommended Citation}

Bennett, Jada M., "Impact of being a West Virginia State FFA President on Career and Personal Accomplishments as Perceived by Past State FFA Presidents 1955 to 2005" (2016). Graduate Theses, Dissertations, and Problem Reports. 5185.

https://researchrepository.wvu.edu/etd/5185

This Thesis is protected by copyright and/or related rights. It has been brought to you by the The Research Repository @ WVU with permission from the rights-holder(s). You are free to use this Thesis in any way that is permitted by the copyright and related rights legislation that applies to your use. For other uses you must obtain permission from the rights-holder(s) directly, unless additional rights are indicated by a Creative Commons license in the record and/ or on the work itself. This Thesis has been accepted for inclusion in WVU Graduate Theses, Dissertations, and Problem Reports collection by an authorized administrator of The Research Repository @ WVU. For more information, please contact researchrepository@mail.wvu.edu. 
Impact of being a West Virginia State FFA President on Career and Personal Accomplishments as Perceived by Past State FFA Presidents 1955 to 2005

Jada M. Bennett

Thesis submitted to the Davis College of Agriculture, Natural Resources and Design at West Virginia University in partial fulfillment of the requirements for the degree of

\title{
Master of Science
} in Agricultural and Extension Education

Deborah A. Boone, Ph.D., Chair

Harry N. Boone, Jr., Ph.D. Stacy A. Gartin, Ph.D.

School of Design and Community Development

\author{
Morgantown, West Virginia \\ 2016
}

Keywords: FFA, State President, State Officer, West Virginia Copyright 2016 Jada M. Bennett 


\begin{abstract}
Impact of being a West Virginia State FFA President on Career and Personal Accomplishments as Perceived by Past State FFA Presidents 1955 to 2005
\end{abstract}

Jada M. Bennett

This descriptive survey study was designed to identify the impact of being a West Virginia State FFA President elected between the years of 1955-2005 on career and personal accomplishments. The population consisted of 51 people who were elected to the office of West Virginia FFA President, the response rate was 69\%. A survey which was composed of four main question sets was mailed to the accessible population.

Questions focused on their SAE and FFA experience, involvement in community and school activities, leadership skills, and demographics. Data were collected and analyzed to identify contributing factors in each of the constructs. The study found that leadership skills were influenced by their FFA experience, specifically being a State President, and the respondents were active members of the community.

Several indicated how FFA had an impact on their lives and they were appreciative of the opportunity. Some remarked that the experience lead them to their current careers. 


\section{ACKNOWLEDGEMENTS}

There are times in your life when things line up perfectly to take you on a great adventure. Sometimes the things that line up seem as though they are horrible situations, but in turn becoming an enormous blessing. My graduate school experience has been one of these amazing blessings. It has taken me down a path I never thought I would go down and allowed me to take the adventure of a lifetime. Along this path have been supporters and key contributors to my success in this program. First, the greatest advisor I could have asked for, Dr. Deborah Boone. Thank you from the bottom of my heart for putting up with me through the last two years. Whether it was needing to vent, asking advice, or threatening to quit; you were the greatest advisor.

Thank you to my other committee members Dr. Harry Boone, and Dr. Stacy Gartin. Dr. Harry, you are such an inspiration to your students and such an amazing mentor through the graduate school process. Dr. Gartin, thank you for your help and motivation and always making sure to ask your students the most important question, "How are you doing?" Without both of you this experience would not have been possible.

Thank you Dr. Gary Wingenbach, Norman Borlaug Institute for International Agriculture, for allowing me the use some of your survey questions. Your research allowed me to have a wonderful starting point for this study.

To my graduate student peers, it was so wonderful taking this ride with you. It was also a little terrifying but let's try to erase the memories of final exams. You were all so helpful in calming me down and helping me reach my goals. Thank you for being there for me and know that I will always be here for you. 
Thank you to my co-workers, Stacey, Sherry, and Margaret for listening to me complain and encouraging me to keep going.

To my loving and supportive family thank you for believing in me. Thank you to my in-laws who were always offering a word of encouragement and understanding when plans were cancelled because of school. Thank you to my best friend, Jesica Streets for being the one person who was always willing to listen to me complain. Thank you to my mom for pushing me, believing in me, and giving me your fighting spirit and belief that things will always work out for the best. Thank you to my dad for instilling the love for agriculture in me at an early age and encouraging me to fight for my dreams. Most importantly, thank you to my wonderful husband, Charlie Bennett, for supporting me, pushing me, and picking me up when all I wanted to do was cry in the corner. You are the greatest husband and I love you so very much.

Graduate school has not been easy, and at times seemed like a bigger hassle than it was worth, but I am so grateful and appreciative of this opportunity and all the people who have helped me through it. 


\section{TABLE OF CONTENTS}

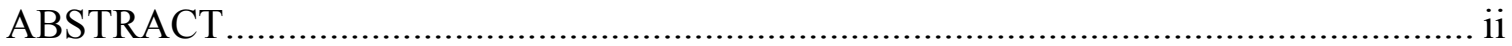

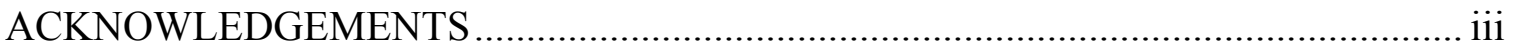

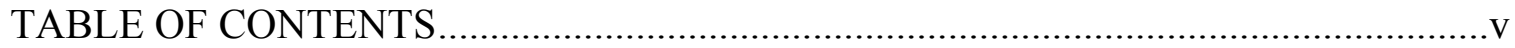

LIST OF TABLES ................................................................................................ vii

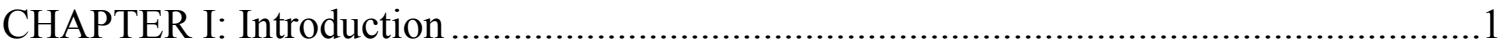

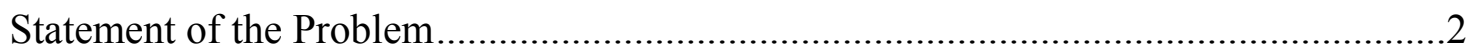

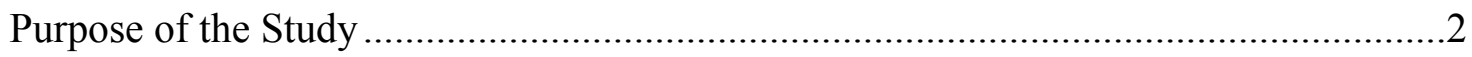

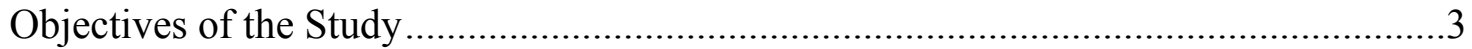

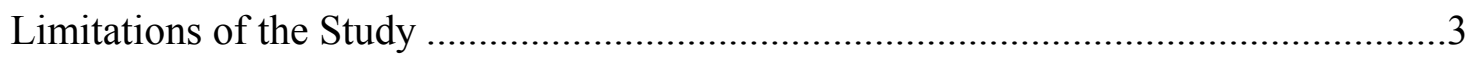

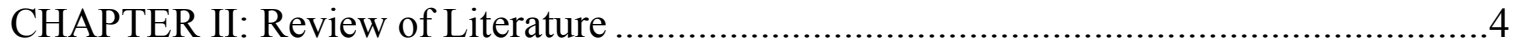

FFA Members Staying in Agriculture Related Fields ...........................................6

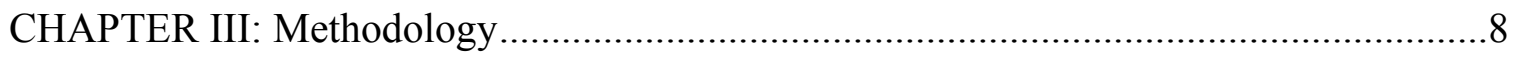

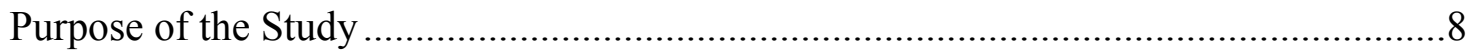

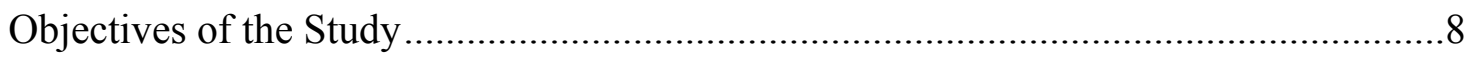

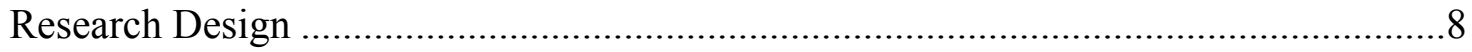

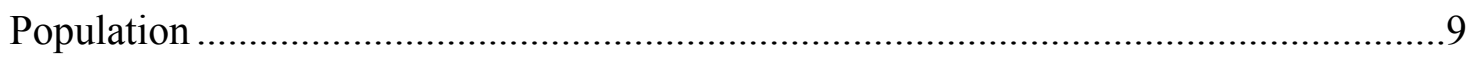

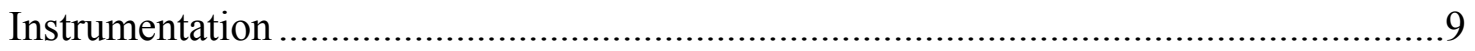

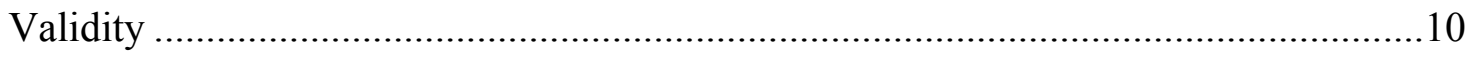

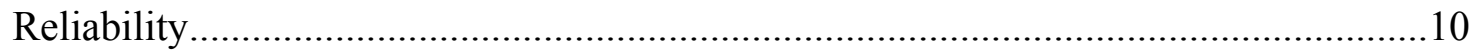

Data Collection Procedure ................................................................................ 10

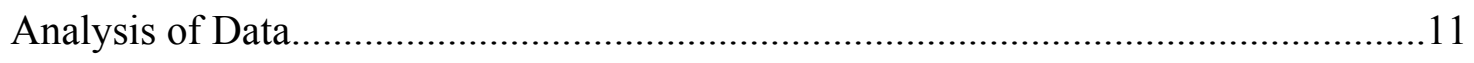

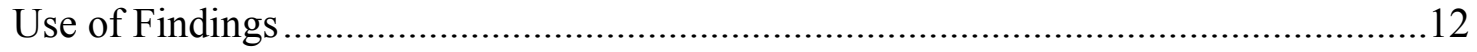


CHAPTER IV: Data Analysis

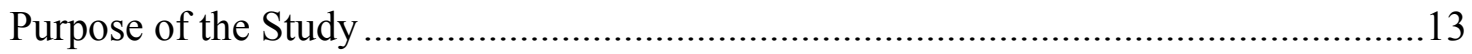

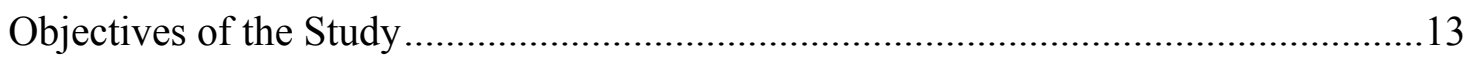

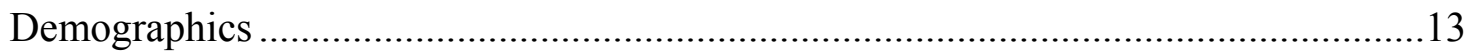

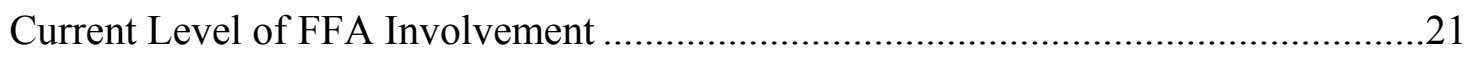

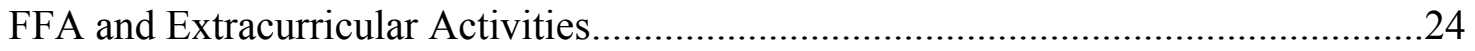

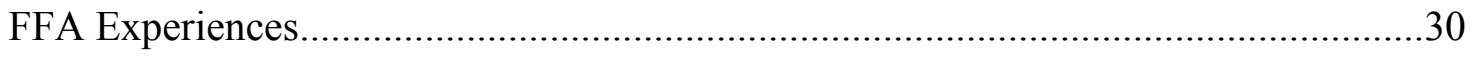

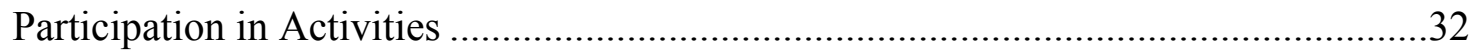

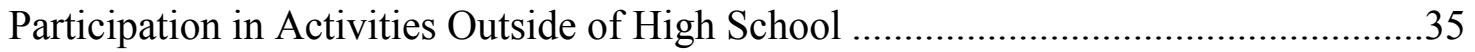

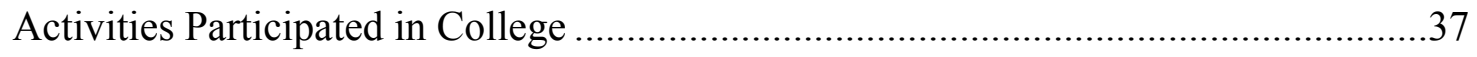

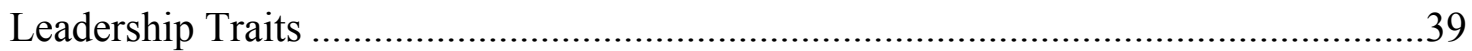

CHAPTER V: Conclusions/Recommendations/Implications.............................................71

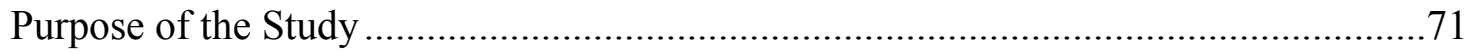

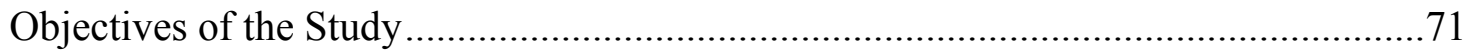

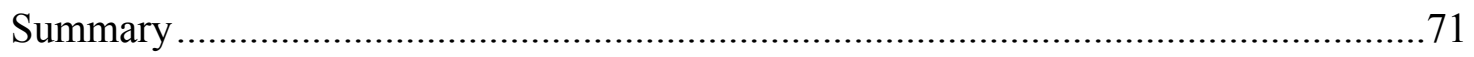

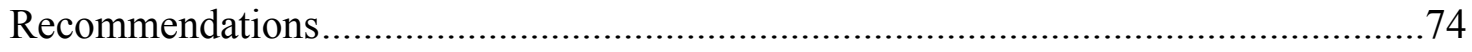

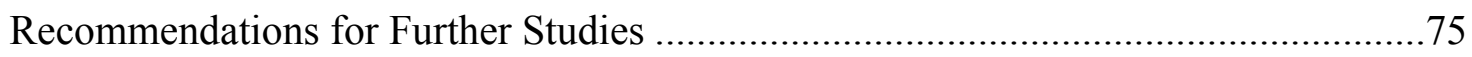

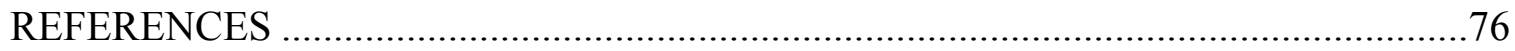

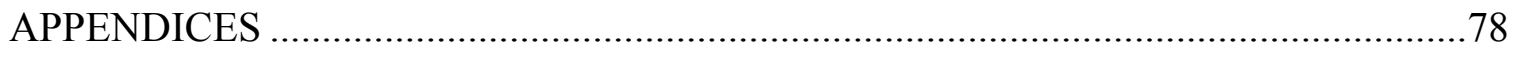

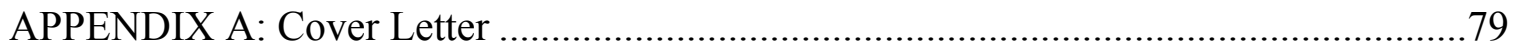

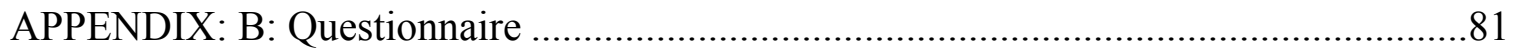

APPENDIX C: Responses to Initial Professional Career ................................................94

Responses to Initial Professional Career ....................................................................95 
APPENDIX D: Responses to Current or at Retirement Professional Career.....

Responses to current or at retirement career .

APPENDIX E: Responses to Organizations Holding Leadership Roles.....

Responses to Organizations Holding Leadership Roles.......................................100

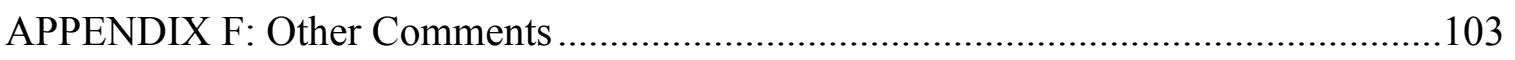

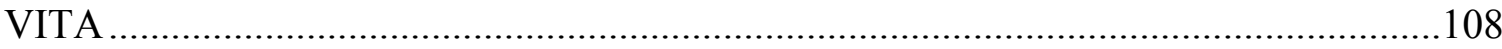




\section{LIST OF TABLES}

Table Title $\quad$ Page

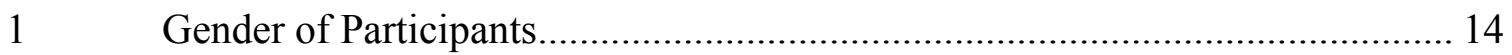

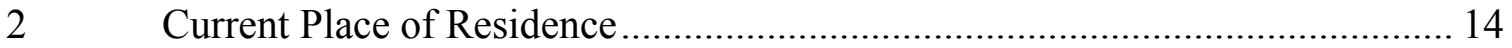

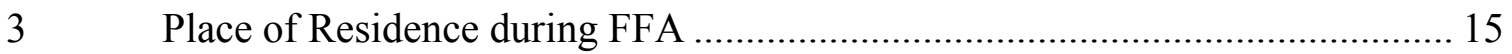

$4 \quad$ Current Employment Status .................................................................... 16

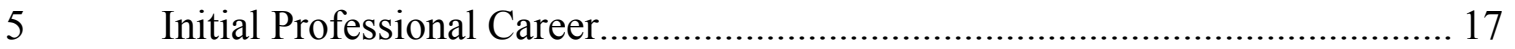

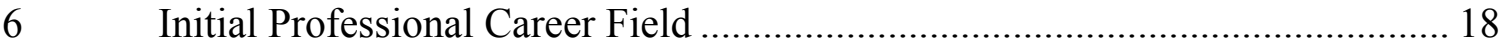

$7 \quad$ Current Job Career Status ........................................................................... 18

$8 \quad$ Current Professional Career Field............................................................... 19

$9 \quad$ Age of Participants at time of Survey ………................................................ 20

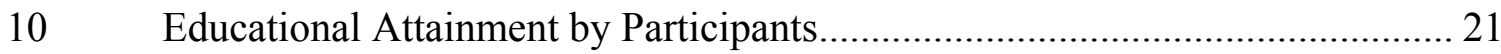

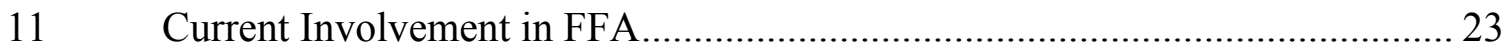

12 Supervised Agriculture Experience of State Presidents..................................... 25

13 Relationship between Careers and SAE ..................................................... 26

14 Chapter Office Held ................................................................................. 27

15 Competitions Competed in as an FFA Member ............................................ 29

$16 \quad$ Competitions Competed in as an FFA Member ............................................ 30

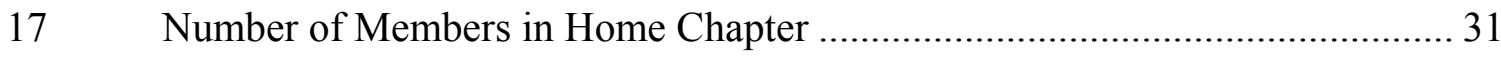

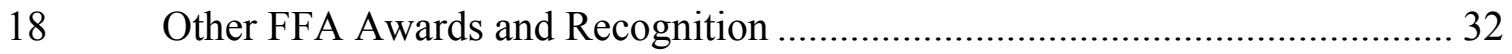

19 Activities Participated in Outside of High School ............................................ 36

20 Activities Participated in College .......................................................... 38

21 Ability to Determine Personal Needs and FFA's Influence …......................... 40 
22 Have a Positive Self-Concept and FFA's Influence

23 Ability to Express Feelings and FFA's Influence 42

Ability to Set Personal Goals and FFA's Influence 43

Ability to Set Group Goals and FFA's Influence 44

Ability to be Honest with Others and FFA's Influence 45

Ability to Use Information to Solve Problems and FFA's Influence 46

Ability to Delegate Responsibility and FFA's Influence

Ability to Set Priorities and FFA's Influence 48

Sensitivity to Others and FFA's Influence. 50

Respondent's Sense of Being Open Minded and FFA's Influence

Consideration for the Needs of Others and FFA's Influence 52

Having a Friendly Personality and FFA's Influence on Personality 54

Considers Input from All Group Members and FFA's Influence. 55

Ability to Listen Effectively and FFA's Influence 56

Ability to Select Alternatives and FFA's Influence. 57

Respect Others and FFA's Influence

42 Ability to be Flexible and FFA's Influence. 62 
45 Ability to Use Rational Thinking and FFA's Influence...................................... 65

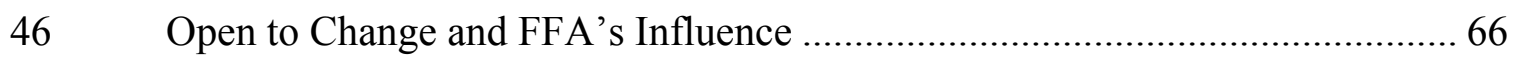

$47 \quad$ Possess Good Manners and FFA's Influence ................................................... 67

$48 \quad$ Ability to Trust Other People and FFA's Influence............................................ 68

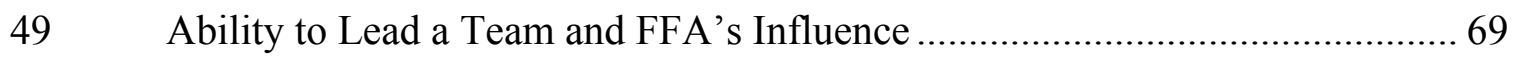

$50 \quad$ Ability to Follow Guidelines and FFA's Influence ………….......................... 70 


\section{CHAPTER I}

\section{Introduction}

The National FFA Organization (FFA) is a youth organization that prides itself on developing students into successful individuals and future leaders. "FFA makes a positive difference in the lives of students by developing their potential for premier leadership, personal growth and career success through agricultural education" (National FFA Organization, 2015, p. 7). In 2015 The National FFA organization reports, “629,367 FFA members, aged 12-21, in 7,757 chapters in all 50 states, Puerto Rico and the U.S. Virgin Islands" (National FFA Organization, 2015, p. 1).

The National FFA organization at all levels works to develop student skills in career fields through training and developing leadership techniques. The question remains as to how effective this training has been in assisting students to develop their leadership skills and reach career goals.

According to the National FFA official manual;

FFA members who take advantage of the many leadership opportunities in FFA become top leaders in the organization. Each state elects a group of student officers to lead its membership for the year. Qualified candidates must have obtained the State FFA Degree. Once elected, state officers engage in a leadership development continuum that reinforces their prior knowledge and trainings for position-related work that builds upon each other... state officers lead the membership of the associations and are 
elected by state convention delegates (National FFA Organization, 2015, p. 48).

A study by Brannon, Holley and Key (1989) found that individuals with a vocational agriculture background had a "higher degree of involvement in community activities than non-vocational agriculture participants" ( $\mathrm{p} 42)$. Wingenbach (1995), found in a study of 316 students taking agriculture classes that leadership opportunities in non FFA related areas was much lower than what FFA offered. The study also found that of the areas of sports, church groups, after school jobs, and 4-H offered the highest leadership opportunities when compared to FFA, but was not higher than FFA.

\section{Statement of the Problem}

Although it is stated that FFA members who take advantage of the many leadership opportunities become top leaders in the organization, little research has been found that addresses the impact of past state officers. Researching how much of an impact, if any, is important in continuing to grow leadership opportunities as well as recruiting more involvement in the FFA top leadership roles. The information from this study will look at the impact of being a WV State FFA President has had on former presidents' lives, both personally and professionally.

\section{Purpose of the Study}

The purpose of this study was to determine if past West Virginia State FFA Presidents and their current career and personal success had any relation to their training during their state presidency. To determine whether the leadership skills they developed through FFA carried over into future endeavors and whether their service to a youth 
organization resulted in them becoming a leader or volunteer in youth or community

organizations later.

\section{Objectives of the Study}

The objectives of the study are reflected in the following research questions:

1. What impact did FFA, and more specifically being a WV FFA State President, have on past state presidents' careers?

2. How active are past state presidents in organizations related to agriculture, as well as organizations unrelated to agriculture, including offices held?

3. What impact did FFA have on current leadership abilities?

4. Are past FFA state presidents still active with FFA at the local, state, or national level (volunteering or as alumni members)?

\section{Limitations of the Study}

Participation in this study was limited to 51 Past West Virginia State FFA Presidents and did not include state presidents from any other state. 


\section{CHAPTER II}

\section{Review of Literature}

Career and Technical Student Organizations (CTSOs) are organizations specifically for students enrolled in Career and Technical Education (CTE) programs. The various organizations engage students by focusing on CTE application activities including developing and practicing leadership roles and learning to apply activities to occupational and academic content. As described by Reese (2011), CTSOs have helped create major leaders in our country including Senators, Governors, Bank and University Presidents, and even former President of the United States, FFA member Jimmy Carter. CTSO programs include DECA, SkillsUSA, Business Professionals of America, The National FFA Organization, and others. The National FFA Organization is able to offer intangible leadership skills as well as tangible skills including, eye contact, using time efficiently, overcoming obstacles, and making wise decisions (Reese, 2011).

Within agricultural education, there are three independent areas that work closely together in order to offer the best experience for students. They include: Supervised Agricultural Experience (SAE), FFA, and classroom/ laboratory experiences (National FFA Organization, 2015). While the three components comprise the agricultural education program, Staller (2001) states that the FFA is the most intense for strength of learning of life skills. Wingenbach (1995) identified life skills as, "skills in communication, decision making, getting along with others, learning, management, understanding self, and working with groups" (p 70).

Hoover, Scholl, Dunigan, and Mamontova (2007) studied FFA and 4-H members and their leadership skills and behaviors. Members were encouraged to attend camps, 
competitive events, and conferences to develop these skills. Through participation, members were able to receive degrees and awards to acknowledge their achievements. The study reported it is important to note the differences in the programs related to their orientation (non-formal vs. formal education). As initially organized and developed, 4-H and FFA shared more similarities than differences as related to the personal growth and leadership development of young people. To date, both youth organizations are still providing subject matter and opportunities in life skill and leadership development (Hoover, Scholl, Dunigan, \& Mamontova, 2007). A main focus of FFA is that through leadership development members will be better prepared for their future careers and other leadership roles. Wingenbach (1995) found the importance of FFA in leadership roles and compare these to other studies. Wingenbach (1995) found that FFA leadership activities had the highest statistical significance in youth leadership and life skills development. Independent variables leading to additional variance was found in the difference in GPA, after school jobs, and club officer positions. Leadership activities and abilities carry over to personal and professional achievement. The various areas of leadership abilities are shown to be affected by FFA and other leadership organizations. A study conducted in Florida on past State FFA Officers found that participants reported that the agriculture program and the FFA contributed the most to their leadership development, followed by community variables, self-variables (gender, self-esteem, motivation, and GPA), family variables, followed by the school variables (Ricketts \& Rudd, 2004). 


\section{FFA Members Staying in Agriculture Related Fields}

There are over 22 million people who work in agricultural related fields in the United States according to the Agricultural Council of America (Adedokum \& Balshweid, 2009). While this is a large portion of the workforce, agriculture related careers are still shorthanded. Understanding what influences students to choose agricultural related careers will help to recruit more students to agricultural fields. Adedokun and Balshweid (2009) found that factors influencing agriculturally related career choices included: membership in 4-H, participation in FFA, preference for living close to natural environment, opportunity to achieve dream career in the rural community and participation in volunteer activities within the community (Adedokum \& Balshweid, 2009).

A study of FFA members on the national level found that one-third of all students aspired to go into agricultural related fields. While a comparison was not made to non FFA members, the number is still much higher than the percentage of people in agriculture related careers (Talbert \& Balschweid, 2006).

Ricketts \& Rudd (2004) studied past State FFA Officers in Florida and found that nearly half of them held careers related to agriculture after they left FFA. The careers ranged from entrepreneurs to lawyers. Most of the study participants were involved in some type of leadership activity and continued to support the FFA. Participants were also found to participate in other leadership activities in the community and believed that training from FFA helped them in those leadership activities as well.

Sims (2014) studied students at West Virginia University Davis College and identified factors which motivated the students to study in an agricultural related field 
and pursue an agricultural related degree. Motivating factors included having career decisions influenced by a teacher, desire to succeed, experiences from having worked on a farm or in an agricultural related business and having taken high school agriculture courses. Sims (2014) also found that pursuit of an agricultural related career was directly related to the prospect of having many career opportunities upon graduation. 


\section{CHAPTER III}

\section{Methodology}

\section{Purpose of the Study}

The purpose of this study was to determine if the past West Virginia State FFA Presidents and their current career and personal success had any relation to their training during their state presidency. To determine whether the leadership skills they developed through FFA carried over into future endeavors and whether their service to a youth organization resulted in them becoming a leader or volunteer in youth or community organizations later.

\section{Objectives of the Study}

The objectives of the study are reflected in the following research questions:

1. What impact did FFA, and more specifically being a WV FFA State President, have on past state presidents' careers?

2. How active are past state presidents in organizations related to agriculture, as well as organizations unrelated to agriculture, including offices held?

3. What impact did FFA have on current leadership abilities?

4. Are past FFA state presidents still active with FFA at the local, state, or national level (volunteering or as alumni members)?

\section{Research Design}

The descriptive research technique was used to gather data for this study. A mailed survey was used to collect data from the population. This allows for qualitative and quantitative information to be collected. Descriptive research asks questions about 
the nature, incidence and distribution of variables, not to manipulate but to describe (Ary, Jacobs, \& Razavieh, 2002).

\section{Population}

A census was conducted of all 51 past state FFA presidents elected from 19552005. This time frame was chosen so as to include individuals who were at various stages in their careers and to exclude individuals who had just entered their careers..

Since an accurate list of all past state FFA presidents was not available, numerous efforts were used to locate current addresses for all 51 individuals who served as state president from1955-2005. Efforts to contact the population included extensive internet research using last known location and calling countless individuals to track down current addresses of individuals. Facebook was used to contact some as well as contacting other individuals who they possibly went to school with or worked with in order to track down the correct individual. Pure luck of running into the right person at the right time helped locate a few of the older past presidents.

\section{Instrumentation}

The survey instrument was developed based a review of literature. Content and face validity were established by a panel of experts consisting of West Virginia University faculty in Agricultural and Extension Education. The study was approved by the West Virginia University Institutional Review Board.

A questionnaire was developed to gather information related to the training the participants received as West Virginia State FFA Presidents and how this influenced their career and personal goals. The survey asked the past state presidents to indicate their current ability in a number of skill areas and then asked them to rate how influential 
being State FFA President was on the development of that skill. A Likert scale was used to measure those questions. Additional questions asked the respondents to indicate what their initial professional careers were and what their current careers were to determine whether their careers were in an agricultural related area or in what career areas they were currently employed. Demographic data were also collected.

\section{Validity}

The instrument was presented to a panel of experts to establish content and face validity. The panel consisted of professors in Agricultural and Extension Education. Each member of the panel had extensive teaching, research, and/or FFA experience. The panel determined that the instrument had content and face validity.

\section{Reliability}

A split half was calculated to determine overall reliability of the instrument, which resulted in a Spearman Brown reliability coefficient of .940. According to Robinson, Shaver, \& Wrightsman (1991) it was found to have exemplary reliability.

\section{Data Collection Procedure}

Data for this study were collected using a mailed questionnaire. The initial packet included a cover letter (see Appendix A), questionnaire (see Appendix B), and a selfaddressed postage paid return envelope. The cover letter explained the purpose of the study and how their participation was essential to the outcome of the study. The first packet was sent out on October 5, 2015 with a request that the survey be returned by October 14, 2015. Phone calls were made to individuals who did not return their surveys to request return of the survey and to inform them a follow-up mailing would be coming shortly. An online survey was developed for those individuals who were overseas or 
were unable to receive a mailed survey. A follow up mailing was sent out on October 19, 2015 with a response date of November 5, 2015. The online survey was offered to those individuals who did not return their surveys. Most declined taking the online survey and stated they would take the paper version. The online survey was utilized by three individuals. Data were compiled in an Excel spreadsheet for analysis on December 15, 2015. There were 51 individuals who received the initial survey, 35 individuals responded to the questionnaire for a response rate of $68.6 \%$.

T-tests were run to compare early and late respondents. When comparing the two categories, no differences were found. Though generalizations could be made to the entire population, the findings of this study will be limited to the respondents.

\section{Analysis of Data}

Due to the instrument being a mixed methods survey, there was a qualitative analysis of open-ended responses addressing perceived obstacles to success within the industry, as well as quantitative analysis to analyze other constructs. Quantitative data were analyzed utilizing the SPSS 23.0 for Windows. The level of significance was set at $\alpha<.05$ for all statistical tests. Descriptive analyses appropriate for the respective scales of measurement were performed on the data including measures of central tendency (mean, median or mode) and variability (frequencies or standard deviation). A comparison of current leadership abilities and perceptions of how FFA influenced those abilities were also analyzed. The results will be represented as frequencies and percentages as well as mean, median and mode in both table and narrative form. 


\section{Use of Findings}

The findings will help to guide individuals who are working with state officer teams on what is needed in trainings. The results will also be helpful in recruiting more state officer prospects as they can see the potential impact from being a State FFA president. 


\section{CHAPTER IV}

\section{Data Analysis}

\section{Purpose of the Study}

The purpose of this study was to determine if the past West Virginia State FFA Presidents and their current career and personal success had any relation to their training during their state presidency. To determine whether the leadership skills they developed through FFA carried over into future endeavors and whether their service to a youth organization resulted in them becoming a leader or volunteer in youth or community organizations later.

\section{Objectives of the Study}

The objectives of the study are reflected in the following research questions:

1. What impact did FFA, and more specifically being a WV FFA State President, have on past state presidents' careers?

2. How active are past state presidents in organizations related to agriculture and unrelated to agriculture, including offices held?

3. What impact did FFA have on current leadership abilities?

4. Are past FFA state presidents still active with FFA at the local, state, or national level (volunteering or as alumni members)?

\section{Demographics}

Respondents were asked to indicate their gender. Of the population, $28(80.00 \%)$ were male and seven individuals $(20.00 \%)$ indicated they were female (see Table 1 ). 
Table 1

Gender of Participants

\begin{tabular}{lcc}
\hline & $\mathrm{N}$ & $\%$ \\
\hline Male & 28 & 80.00 \\
Female & 7 & 20.00 \\
\hline
\end{tabular}

The participants were asked to indicate their current place of residence. Of the respondents, $13(37.14 \%)$ stated they live on a farm and $13(37.14 \%)$ reported they live in rural non-farm area. Three of the participants indicated they live in a town or city with $10,000-49,000$ people while six participants $(17.14 \%)$ reported they live in suburb or city over 50,000 (see Table 2).

Table 2

Current Place of Residence

\begin{tabular}{lcc}
\hline & $\mathrm{N}$ & $\%$ \\
\hline Farm & 13 & 37.14 \\
Rural non-farm & 13 & 37.14 \\
Town or city 10,000-49,999 & 3 & 8.57 \\
Suburb or City over 50,000 & 6 & 17.14 \\
\hline
\end{tabular}

The respondents were asked to indicate their place of residence during FFA. Of the answers, $26(74.29 \%)$ stated they live on a farm and nine $(25.71 \%)$ replied they live in rural non-farm (see Table 3). 
Table 3

Place of Residence during FFA

\begin{tabular}{lcc}
\hline & $\mathrm{N}$ & $\%$ \\
\hline Farm & 26 & 74.29 \\
Rural non-farm & 9 & 25.71 \\
Town or city 10,000-49,999 & 0 & 0.00 \\
Suburb or City over 50,000 & 0 & 0.00 \\
\hline
\end{tabular}

The participants were asked for their current employment status. Of the respondents $16(45.71 \%)$ stated they had full-time off-farm employment with no farming, while two $(5.71 \%)$ reported they have part-time off-farm employment with no farming. Nine $(25.71 \%)$ reported working at full-time off-farm employment with part time farming and one $(2.86 \%)$ indicated they were a full time farmer with no outside employment. One $(2.86 \%)$ reported they were retired and part time farmer, one $(2.86 \%)$ reported they were retired and full time farmer, and five (14.29\%) responded as retired, not farming (see Table 4). 
Table 4

Current Employment Status

\begin{tabular}{llc}
\hline & $\mathrm{N}$ & $\%$ \\
\hline $\begin{array}{ll}\text { Full-time off-farm employment - no farming } \\
\text { Part-time off-farm employment - no farming }\end{array}$ & 16 & 45.71 \\
$\begin{array}{l}\text { Full-time off-farm employment - part-time } \\
\text { farming }\end{array}$ & 9 & 5.71 \\
$\begin{array}{l}\text { Full time farmer - part time off-farm } \\
\text { employment }\end{array}$ & 0 & 25.71 \\
$\begin{array}{l}\text { Full time farmer - full time off-farm } \\
\text { employment }\end{array}$ & 0 & 0.00 \\
$\begin{array}{l}\text { Full time farmer no outside employment } \\
\text { Part time farmer with part time off-farm }\end{array}$ & 1 & 0.00 \\
employment & & 2.86 \\
Retired and part time farmer & 0 & 0.00 \\
Retired and full time farmer & 1 & 2.86 \\
\begin{tabular}{l} 
Retired \\
\hline
\end{tabular} & 1 & 2.86 \\
\hline
\end{tabular}

Participants were asked whether their initial professional career was agriculturally related. Of the respondents 17 (53.13\%) indicated their initial employment was agriculturally related and $15(46.88 \%)$ reported their jobs were not agriculturally related (see Table 5). 
Table 5

Initial Professional Career

\begin{tabular}{lcc}
\hline & $\mathrm{N}$ & $\%$ \\
\hline Agricultural Related & 17 & 53.13 \\
Non-agricultural Related & 15 & 46.88 \\
\hline
\end{tabular}

The participants were asked what career field their initial professional career fell under. Of the responses, $10(29.41 \%)$ had education and training career fields and seven $(20.59 \%)$ had agriculture, food and natural resources careers. Five (14.71\%) responded having human services positions and three (8.82\%) specified to have law, public safety, corrections, and security careers. Transportation, distribution, and logistics made up two $(5.88 \%)$ participants and one participant reported having a finance career. At least one $(2.94 \%)$ participant reported to have an initial career in each of the following areas: health science, hospitality and tourism, marketing sales and service, and science technology engineering and mathematics (see Table 6). 
Table 6

Initial Professional Career Field

\begin{tabular}{llc}
\hline & $\mathrm{N}$ & $\%$ \\
\hline Education and Training & 10 & 29.41 \\
Agriculture, Food and Natural Resources & 7 & 20.59 \\
Human Services & 5 & 14.71 \\
Law, Public Safety, Corrections, and Security & 3 & 8.82 \\
Government and Public Administration & 2 & 5.88 \\
Transportation, Distribution and Logistics & 2 & 5.88 \\
Finance & 1 & 2.94 \\
Health Science & 1 & 2.94 \\
Hospitality and Tourism & 1 & 2.94 \\
Marketing, Sales and Service & 1 & 2.94 \\
Science, Technology, Engineering, and & & 2.94 \\
Mathematics & 1 & \\
\hline
\end{tabular}

Respondents were asked whether their current professional career was agricultural related. Of the respondents $14(41.18 \%)$ responded their jobs were agriculturally related and $20(58.82 \%)$ designated their jobs were not agriculturally related (see Table 7).

Table 7

Current Job Career Status

\begin{tabular}{lcc}
\hline & $\mathrm{N}$ & $\%$ \\
\hline Agricultural Related & 14 & 41.18 \\
Non-agricultural Related & 20 & 58.82 \\
\hline
\end{tabular}


Respondents were asked their current career classification. Of the responses, 10 (30.30\%) had education and training career fields and seven (21.21\%) had agriculture, food and natural resources careers. Seven (21.21\%) indicating human services positions and two $(6.06 \%)$ reported to have law, public safety, corrections, and security careers. A government and public administration career was reported by one (3.03\%) respondent. Transportation, distribution, and logistics had one (3.03\%) response and two (6.06\%) contributors stated they had a finance career. The following areas had one respondent each (3.03\%): business management and administration, marketing sales and service, and science, technology, engineering, and mathematics (see Table 8).

Table 8

Current Professional Career Field

\begin{tabular}{llc}
\hline & $\mathrm{N}$ & $\%$ \\
\hline Education and Training & 10 & 30.30 \\
Agriculture, Food and Natural Resources & 7 & 21.21 \\
Human Services & 7 & 21.21 \\
Law, Public Safety, Corrections, and Security & 2 & 6.06 \\
Government and Public Administration & 1 & 3.03 \\
Transportation, Distribution and Logistics & 1 & 3.03 \\
Finance & 2 & 6.06 \\
Business Management and Administration & 1 & 3.03 \\
Marketing, Sales and Service & 1 & 3.03 \\
Science, Technology, Engineering, and & & 3.03 \\
Mathematics & 1 & \\
\hline
\end{tabular}


The population was asked to indicate their age during the time of this survey by selecting a category from the ordinal scale provided. Three individuals $(8.57 \%)$ indicated they were 30 years and below. Four respondents (11.43\%) indicated they were between $31-40$ years, while eight individuals $(22.86 \%)$ indicated they were $41-50$ years old, and eight respondents $(22.86 \%)$ indicated they were 51-60 years old. There were six respondents $(22.86 \%)$ who indicated they were 61-70 years old and six respondents $(22.86 \%)$ who indicated they were over 70 years (see Table 9$)$.

Table 9

Age of Participants at time of Survey

\begin{tabular}{lcc}
\hline & $\mathrm{N}$ & $\%$ \\
\hline 30 years and below & 3 & 8.57 \\
$31-40$ years & 4 & 11.43 \\
$41-50$ years & 8 & 22.86 \\
$51-60$ years & 8 & 22.86 \\
$61-70$ years & 6 & 17.14 \\
Over 70 years & 6 & 17.14 \\
\hline
\end{tabular}

Participants were asked what degrees they held. Of the participants, 35 (100\%) had graduated high school, one $(2.86 \%)$ respondent attended some college and one $(2.86 \%)$ respondent had received a technical certificate. Five $(14.29 \%)$ participants had earned a two-year degree and $30(85.71 \%)$ respondents had a four-year degree. Nineteen respondents (55.88\%) reported they had received a Master's Degree, four $(11.76 \%)$ had earned their PhD, and 12 (35.29\%) had earned a Professional degree (see Table 10). 
Table 10

Educational Attainment by Participants

\begin{tabular}{lcccc}
\hline & \multicolumn{2}{c}{ Yes } & \multicolumn{2}{c}{ No } \\
\cline { 2 - 5 } & $\mathrm{N}$ & $\%$ & $\mathrm{~N}$ & $\%$ \\
\hline Did not graduate high school & 0 & 0.00 & 35 & 100.00 \\
Received High school diploma or equivalent & 35 & 100.00 & 0 & 0.00 \\
Went to Some College & 1 & 2.86 & 34 & 97.14 \\
Received Technical Certification & 1 & 2.86 & 34 & 97.14 \\
Received Two-year degree & 5 & 14.29 & 30 & 85.71 \\
Received four-year degree & 30 & 85.71 & 5 & 14.29 \\
Received Masters Graduate Degree & 19 & 55.88 & 16 & 44.12 \\
Received PhD & 4 & 11.42 & 31 & 88.57 \\
Received Professional Degree & 12 & 34.29 & 23 & 65.71 \\
\hline
\end{tabular}

\section{Current Level of FFA Involvement}

The survey asked past West Virginia State Presidents what their current level of involvement in FFA. The following results were recorded.

Respondents were asked if they had received honorary membership at any level.

Of the individuals who had received honorary membership, 14 (41.18\%) had received Chapter Honorary, one (2.94\%) had received Regional/ District Honorary, 11 (32.35\%) have received their State Honorary, and six (17.65\%) had received their National Honorary degree (see Table 11).

The participants were asked if they were FFA Alumni or booster members. Of the individuals who reported being alumni or booster, members $14(41.18 \%)$ are chapter 
alumni, one (2.94\%) is a regional/district alumni member, five (14.71\%) was state alumni/booster members, and one (2.94\%) was a national alumni member (see Table 11).

Participants were asked about their fundraiser support. Of the individuals who responded they were fundraiser supporters, 15 (44.12\%) were at the chapter level, two $(5.88 \%)$ were at the regional/district level, three $(8.82 \%)$ were at the state level, and none of the respondents were national fundraiser supporters (see Table 11).

The respondents were asked if they were team coaches. Of the individuals who were team coaches, seven $(20.59 \%)$ were at the chapter level, five (14.71\%) were at the regional/district level, five (14.71\%) were at the state level, and two were at the national level (see Table 11).

Participants were asked about if they were monetary supporters. Of the individuals who were monetary supporters, $11(32.35 \%)$ were at a chapter level, three $(8.82 \%)$ were at the regional/district level, seven $(20.59 \%)$ were at the State level, and one is at the national level (see Table 11).

Respondents were asked about if they were volunteers. Of the individuals who were Volunteers, $14(41.18 \%)$ were at a chapter level, three $(8.82 \%)$ were at the regional/ district level, six (17.65\%) are at the state level, and one (2.94\%) was at the national level (see Table 11). 
Table 11

Current Involvement in FFA

\begin{tabular}{|c|c|c|c|c|}
\hline & \multicolumn{2}{|c|}{ Involved } & \multicolumn{2}{|c|}{ Not Involved } \\
\hline & $\mathrm{N}$ & $\%$ & $\mathrm{~N}$ & $\%$ \\
\hline \multicolumn{5}{|l|}{ Honorary Membership } \\
\hline Chapter & 14 & 41.18 & 20 & 58.82 \\
\hline Regional -District & 1 & 2.94 & 33 & 97.06 \\
\hline State & 11 & 32.35 & 23 & 67.65 \\
\hline National & 6 & 17.65 & 28 & 82.35 \\
\hline \multicolumn{5}{|c|}{ Alumni - Booster Member } \\
\hline Chapter & 14 & 41.18 & 20 & 58.82 \\
\hline Regional -District & 1 & 2.94 & 33 & 97.06 \\
\hline State & 5 & 14.71 & 29 & 85.29 \\
\hline National & 1 & 2.94 & 33 & 97.06 \\
\hline \multicolumn{5}{|l|}{ Fundraiser Supporter } \\
\hline Chapter & 15 & 44.12 & 19 & 55.88 \\
\hline Regional -District & 2 & 5.88 & 32 & 94.12 \\
\hline State & 3 & 8.82 & 31 & 91.18 \\
\hline National & 0 & 0.00 & 34 & 100.00 \\
\hline \multicolumn{5}{|l|}{ Team Coach } \\
\hline Chapter & 7 & 20.59 & 27 & 79.41 \\
\hline Regional -District & 5 & 14.71 & 29 & 85.29 \\
\hline State & 5 & 14.71 & 29 & 85.29 \\
\hline National & 2 & 5.88 & 32 & 94.12 \\
\hline
\end{tabular}


Table 11 (continued)

Current Involvement in FFA

\begin{tabular}{lcccc}
\hline & \multicolumn{2}{c}{ Involved } & \multicolumn{2}{c}{ Not Involved } \\
\cline { 2 - 5 } & $\mathrm{N}$ & $\%$ & $\mathrm{~N}$ & $\%$ \\
\hline Monetary Supporter & 11 & 32.35 & 23 & 67.65 \\
Chapter & 3 & 8.82 & 31 & 91.18 \\
Regional -District & 7 & 20.59 & 27 & 79.41 \\
State & 1 & 2.94 & 33 & 97.06 \\
National & & & & \\
\hline Volunteer & 14 & 41.18 & 20 & 58.82 \\
Chapter & 3 & 8.82 & 31 & 91.18 \\
Regional -District & 6 & 17.65 & 28 & 82.35 \\
State & 1 & 2.94 & 33 & 97.06 \\
National & & & & \\
\hline
\end{tabular}

\section{FFA and Extracurricular Activities}

Respondents were asked to answer questions regarding their FFA and extracurricular activities during high school and college. Thirty-three participants responded to the question about what area their Supervised Agriculture Experience Program (SAE) fell under while they were an FFA member, respondents could give more than one response. "Entrepreneurship" was reported to be the SAE area for $29(87.77 \%)$ respondents, "placement" was the area identified by nine $(27.27 \%)$ respondents, and five (15.15\%) respondents reported their SAE was related to "School Based Enterprise." Eleven participants (33.33\%) reported their SAE was "Service Learning” based, while 
four respondents $(12.12 \%)$ indicated "Home Improvement" was the area aligned with their SAE. "Research exploratory" was not reported to be the SAE for any of the respondents $(0.00 \%)$ (see Table 12$)$.

Table 12

Supervised Agriculture Experience of State Presidents

\begin{tabular}{lcccc}
\hline & \multicolumn{3}{c}{ Yes } & \multicolumn{2}{c}{ No } \\
\cline { 2 - 5 } & $\mathrm{N}$ & $\%$ & $\mathrm{~N}$ & $\%$ \\
\hline Entrepreneurship & 29 & 87.88 & 4 & 12.12 \\
Placement & 9 & 27.27 & 24 & 72.73 \\
Research Exploratory & 0 & 0.00 & 33 & 100.00 \\
School Based Enterprise & 5 & 15.15 & 28 & 84.85 \\
Service Learning & 11 & 33.33 & 22 & 66.67 \\
Home Improvement & 4 & 12.12 & 29 & 87.88 \\
\hline
\end{tabular}

The participants were asked what relationship existed between their initial professional job and their SAE. Seven participants (20.58\%) reported there was "no relationship," six (17.64\%) participants indicated there was "some relationship," four $(11.76 \%)$ respondents noted there was an "average relationship," and 17 (50\%) participants indicated a "strong relationship" existed between their SAE and their initial professional job (see Table 13).

The respondents were asked to indicate the relationship between their SAE and their current job or at retirement. Nine $(26.47 \%)$ respondents reported there was "no relationship," seven (20.59\%) respondents indicated there was "some relationship," four 
(11.76\%) responded there was an "average relationship," and 14 (41.18\%) participants reported a "strong relationship" (see Table 13).

Table 13

Relationship between Careers and SAE

\begin{tabular}{|c|c|c|c|c|c|c|c|c|}
\hline & \multicolumn{2}{|c|}{$\begin{array}{c}\text { No } \\
\text { Relationship }\end{array}$} & \multicolumn{2}{|c|}{$\begin{array}{c}\text { Some } \\
\text { Relationship }\end{array}$} & \multicolumn{2}{|c|}{$\begin{array}{c}\text { Average } \\
\text { Relationship }\end{array}$} & \multicolumn{2}{|c|}{$\begin{array}{c}\text { Strong } \\
\text { Relationship }\end{array}$} \\
\hline & $\mathrm{N}$ & $\%$ & $\mathrm{~N}$ & $\%$ & $\mathrm{~N}$ & $\%$ & $\mathrm{~N}$ & $\%$ \\
\hline $\begin{array}{l}\text { Relationship betw } \\
\text { SAE and Initial }\end{array}$ & & & & & & & & \\
\hline Professional Job & 7 & 20.58 & 6 & 17.64 & 4 & 11.76 & 17 & 50.00 \\
\hline $\begin{array}{l}\text { Relationship betw } \\
\text { SAE and Current } \\
\text { Retirement }\end{array}$ & & & & & & & & \\
\hline Professional Job & 9 & 26.47 & 7 & 20.59 & 4 & 11.76 & 14 & 41.18 \\
\hline
\end{tabular}

Thirty-five participants responded when asked what chapter offices they had held in FFA. Twenty-five (71.43\%) reported they had been chapter president, 17 (48.57\%) had been chapter vice president, 13 (37.14\%) had been chapter secretary, and six (17.14\%) participants reported they had served as chapter treasurer. The offices of reporter and sentinel had each been held by five (14.29\%) respondents. Two (5.71\%) respondents indicated they had been chapter historian, while both parliamentarian and assistant/junior vice president had been held by three (8.57\%) respondents each. There were no respondents who indicated they held the position of chaplain, assistant/junior president, assistant/junior secretary, assistant/junior treasurer, assistant/junior reporter, assistant/junior sentinel, assistant/junior historian, assistant/junior parliamentarian, assistant/junior chaplain (see Table 14). 
Table 14

Chapter Office Held

\begin{tabular}{lcccc}
\hline & \multicolumn{2}{c}{ Yes } & \multicolumn{2}{c}{ No } \\
\cline { 2 - 5 } & $\mathrm{N}$ & $\%$ & 10 & $\%$ \\
\hline President & 25 & 71.43 & 18 & 51.43 \\
Vice President & 17 & 48.57 & 22 & 62.86 \\
Secretary & 13 & 37.14 & 29 & 82.86 \\
Treasurer & 6 & 17.14 & 30 & 85.71 \\
Reporter & 5 & 14.29 & 30 & 85.71 \\
Sentinel & 5 & 14.29 & 33 & 94.29 \\
Historian & 2 & 5.71 & 32 & 91.43 \\
Parliamentarian & 3 & 8.57 & & 91.43 \\
Assistant - Junior Vice & & 8.57 & 32 & \\
President & 3 & & & \\
\hline
\end{tabular}

The participants were asked what competitions they competed in as FFA members and at what was their highest level of competition; chapter, regional/district, state, or national level. In creed speaking, 15 (42.86\%) participated at the chapter level, $14(40.00 \%)$ competed at the regional/ district level, three $(8.57 \%)$ competed at the state level, none of the respondents competed at the national level and three $(8.57 \%)$ did not participate at any level (see Table 4). With regard to the agriscience fair, one $(2.86 \%)$ respondent competed at the chapter level, one (2.86\%) competed at the regional/district level, seven $(20.00 \%)$ competed at the state level, none of the respondents competed at the national level and $26(74.29 \%)$ did not participate in this event at any level. In the 
area of agricultural communications, one (2.86\%) participated at the chapter level, one $(2.86 \%)$ competed at the regional/district level, four $(11.43 \%)$ competed at the state level, and one $(2.86 \%)$ competed at the national level, while $28(80.00 \%)$ did not participate in this event at any level (see Table 15).

In the event agricultural issues forum, one (2.86\%) respondent participated at the chapter level, one (2.86\%) competed at the regional/district level, one $(2.86 \%)$ competed at the state level, none of the respondents competed at the national level and 32 (91.43\%) did not participate in this event at any level. In the event Extemporaneous Public Speaking, six (17.14\%) participated at the chapter level, five (14.29\%) competed at the regional/district level, four (11.43\%) competed at the state level, two (5.71\%) competed at the national level and 18 did not participate in this event at any level.

Responses for job interview reported one $(2.86 \%)$ respondent participated at the chapter level, none of the respondents competed at the regional/district, state, or national level, while 34 (97.14\%) did not participate at any level. For Parliamentary Procedure, 15 (42.86\%) respondents competed at the regional/district level, 15 (42.86\%) competed at the state level, three (8.57\%) competed at the national level, two (5.71\%) did not participate on any level and none of the respondents participated in this event at the chapter level (see Table 15).

For the event prepared public speaking five (14.29\%) respondents reported they participated at the chapter level, $11(31.43 \%)$ competed at the regional/district level, five (14.29\%) competed at the state level, four (11.43\%) competed at the national level and 10 (28.57\%) respondents did not participate in this event at any level. In response to various 
Career Development Events, two (5.71\%) respondents indicated they had participated at the chapter level, one (2.86\%) competed at the regional/district level, four (11.43\%) competed at the state level, and nine (25.71\%) competed at the national level and 19 (54.29\%) did not participate in these events at any level. Of the respondents, $23(65.71 \%)$ reported that they did not participate in Other Events Not Listed, three (8.57\%) indicated they had competed at the regional/district level, five (14.29\%) competed at the state level, and four (11.43\%) competed at the national level in the following events: beef expo, land judging (4), sheep shearing, ham, bacon and egg show (HBE), proficiency awards, and others not specified (see Table 15).

Table 15

Competitions Competed in as an FFA Member

\begin{tabular}{lccccccccccc}
\hline & $\begin{array}{c}\text { Did Not } \\
\text { Participate }\end{array}$ & Chapter & \multicolumn{2}{c}{$\begin{array}{c}\text { Regional- } \\
\text { District }\end{array}$} & \multicolumn{2}{c}{ State } & \multicolumn{2}{c}{ National } \\
\cline { 2 - 10 } & $\mathrm{N}$ & $\%$ & $\mathrm{~N}$ & $\%$ & $\mathrm{~N}$ & $\%$ & $\mathrm{~N}$ & $\%$ & $\mathrm{~N}$ & $\%$ \\
\hline Creed Speaking & 3 & 8.57 & 15 & 42.86 & 14 & 40.00 & 3 & 8.57 & 0 & 0.00 \\
Agriscience Fair & 26 & 74.29 & 1 & 2.86 & 1 & 2.86 & 7 & 20.00 & 0 & 0.00 \\
$\begin{array}{l}\text { Agricultural } \\
\text { Communications }\end{array}$ & 28 & 80.00 & 1 & 2.86 & 1 & 2.86 & 4 & 11.43 & 1 & 2.86 \\
$\begin{array}{l}\text { Agricultural } \\
\text { Issues Forum }\end{array}$ & 32 & 91.43 & 1 & 2.86 & 1 & 2.86 & 1 & 2.86 & 0 & 0.00 \\
$\begin{array}{l}\text { Extemporaneous } \\
\text { Public Speaking }\end{array}$ & 18 & 51.43 & 6 & 17.14 & 5 & 14.29 & 4 & 11.43 & 2 & 5.71 \\
Job Interview & 34 & 97.14 & 1 & 2.86 & 0 & 0.00 & 0 & 0.00 & 0 & 0.00 \\
\hline
\end{tabular}


Table 15 (continued)

Competitions Competed in as an FFA Member

\begin{tabular}{|c|c|c|c|c|c|c|c|c|c|c|}
\hline & \multicolumn{2}{|c|}{$\begin{array}{c}\text { Did Not } \\
\text { Participate }\end{array}$} & \multicolumn{2}{|c|}{ Chapter } & \multicolumn{2}{|c|}{$\begin{array}{l}\text { Regional- } \\
\text { District }\end{array}$} & \multicolumn{2}{|c|}{ State } & \multicolumn{2}{|c|}{ National } \\
\hline & $\mathrm{N}$ & $\%$ & $\mathrm{~N}$ & $\%$ & $\mathrm{~N}$ & $\%$ & $\mathrm{~N}$ & $\%$ & $\mathrm{~N}$ & $\%$ \\
\hline \multicolumn{11}{|l|}{ Parliamentary } \\
\hline Procedure & 2 & 5.71 & 0 & 0.00 & 15 & 42.86 & 15 & 42.86 & 3 & 8.57 \\
\hline \multicolumn{11}{|l|}{ Prepared Public } \\
\hline Speaking & 10 & 28.57 & 5 & 14.29 & 11 & 31.43 & 5 & 14.29 & 4 & 11.43 \\
\hline \multicolumn{11}{|l|}{ Career } \\
\hline Speaking & 19 & 54.29 & 2 & 5.71 & 1 & 2.86 & 4 & 11.43 & 9 & 25.71 \\
\hline Other & 23 & 65.71 & 0 & 0.00 & 3 & 8.57 & 5 & 14.29 & 4 & 11.43 \\
\hline
\end{tabular}

\section{FFA Experiences}

Participants were asked about their home chapter membership at the time of them becoming West Virginia FFA State President. Two (5.71\%) respondents reported they had 1-30 members in their home chapter, while 11(31.43\%) participants indicated there were 31-60 members. Six (17.14\%) participants responded that they had 61-90 members, $10(28.57 \%)$ participants reported there were $91-120$ members, and three $(8.57 \%)$ participants indicated they had 121-150 members in their home chapter. One $(2.86 \%)$ participant reported 151-180 members, and two (5.71\%) participants indicated there were 180 and over members in their home chapter (see Table 16). 
Table 16

Number of Members in Home Chapter

\begin{tabular}{lcc}
\hline & $\mathrm{N}$ & $\%$ \\
\hline $1-30$ & 2 & 5.71 \\
$31-60$ & 11 & 31.43 \\
$61-90$ & 6 & 17.14 \\
$91-120$ & 10 & 28.57 \\
$121-150$ & 3 & 8.57 \\
$151-180$ & 1 & 2.86 \\
181 and over & 2 & 5.71 \\
\hline
\end{tabular}

Participants were asked about receiving their American FFA/Farmer Degree, running for National FFA Officer, and holding an office other than WV FFA State President. Twenty-one (60.00\%) respondents indicated they had received their American FFA/Farmer Degree, eight (22.86\%) respondents had run for a National Office, and 29 $(82.86 \%)$ reported they had served as a state officer other than West Virginia FFA State President (see Table 17). 
Table 17

Other FFA Awards and Recognition

\begin{tabular}{lcccc}
\hline & \multicolumn{2}{c}{ Yes } & \multicolumn{2}{c}{ No } \\
\cline { 2 - 5 } & $\mathrm{N}$ & $\%$ & $\mathrm{~N}$ & $\%$ \\
\hline $\begin{array}{l}\text { Received American FFA- American } \\
\text { Farmer Degree }\end{array}$ & 21 & 60.00 & 14 & 40.00 \\
Ran for National FFA Office & 8 & 22.86 & 27 & 77.14 \\
$\begin{array}{l}\text { Served as State Officer other than } \\
\text { State President }\end{array}$ & 29 & 82.86 & 6 & 17.14 \\
\hline
\end{tabular}

\section{Participation in Activities}

The participants were asked to indicate which activities they had participated in while in high school, other than FFA, and what their highest level of participation was; did not participate, member, chapter officer, regional/district officer, state officer, or national officer. For Student Council six (18.18\%) reported they were members, 11 $(33.33 \%)$ served as chapter officer, one $(3.03 \%)$ was a regional/district officer, one (3.03\%) reported being a state officer, while $14(42.42 \%)$ did not participate in Student Council on any level (see Table 7). As for serving as a Class Officer, two (6.25\%) respondents reported they were members, 15 (46.88\%) reported being a chapter officer, and two $(6.25 \%)$ were a state officer. When asked if they were a club officer for a club other than FFA, three (9.68\%) reported they were members, $15(48.39 \%)$ participated as chapter officer, two (6.45\%) participated as a state officer, while $10(32.26 \%)$ did not participate as a club officer. 
When asked about drama, 17 (62.96\%) respondents reported they did not participate in drama, seven $(25.93 \%)$ indicated they were members, one $(3.70 \%)$ was a chapter officer, and two (7.41\%) were state officers. With regard to participation in band, $20(71.43 \%)$ respondents reported they did not participate in band while eight $(28.57 \%)$ reported they were members of band. Ten $(32.26 \%)$ respondents reported they did not participate in sports, $16(51.61 \%)$ were members, four (12.90\%) participated as a chapter officer and one (3.23\%) participated as a regional/district officer in sports. There were 23 (88.46\%) respondents who did not participate in FHA-FCCLA, two (7.69\%) who were members, and one (3.85\%) was a chapter officer for FHA-FCCLA. None of the respondents reported participation in DECA, VICA, FBLA, SkillsUSA, or TSA organizations (see Table 18). 
Table 18

Activities Participated in During High School

\begin{tabular}{|c|c|c|c|c|c|c|c|c|c|c|c|c|}
\hline & \multicolumn{2}{|c|}{$\begin{array}{c}\text { Did Not } \\
\text { Participate }\end{array}$} & \multicolumn{2}{|c|}{ Member } & \multicolumn{2}{|c|}{ Chapter Officer } & \multicolumn{2}{|c|}{$\begin{array}{c}\text { Regional- } \\
\text { District Officer }\end{array}$} & \multicolumn{2}{|c|}{ State Officer } & \multicolumn{2}{|c|}{ National Officer } \\
\hline & $\mathrm{N}$ & $\%$ & & $\%$ & $\mathrm{~N}$ & $\%$ & $\mathrm{~N}$ & $\%$ & $\mathrm{~N}$ & $\%$ & $\mathrm{~N}$ & $\%$ \\
\hline Student Council & 14 & 42.42 & 6 & 18.18 & 11 & 33.33 & 1 & 3.03 & 1 & 3.03 & 0 & 0.00 \\
\hline Class Officer & 13 & 40.63 & 2 & 6.25 & 15 & 46.88 & 0 & 0.00 & 2 & 6.25 & 0 & 0.00 \\
\hline Club Officer & 10 & 32.26 & 3 & 9.68 & 15 & 48.39 & 1 & 3.23 & 2 & 6.45 & 0 & 0.00 \\
\hline Drama & 17 & 62.49 & 7 & 25.93 & 1 & 3.70 & 0 & 0.00 & 2 & 7.41 & 0 & 0.00 \\
\hline Band & 20 & 71.43 & 8 & 28.57 & 0 & 0.00 & 0 & 0.00 & 0 & 0.00 & 0 & 0.00 \\
\hline TSA & 25 & 100.00 & 0 & 0.00 & 0 & 0.00 & 0 & 0.00 & 0 & 0.00 & 0 & 0.00 \\
\hline Sports & 10 & 32.26 & 16 & 51.61 & 4 & 12.90 & 11 & 3.23 & 0 & 0.00 & 0 & 0.00 \\
\hline FHA-FCCLA & 23 & 88.46 & 2 & 7.69 & 1 & 3.85 & 0 & 0.00 & 0 & 0.00 & 0 & 0.00 \\
\hline DECA & 25 & 100.00 & 0 & 0.00 & 0 & 0.00 & 0 & 0.00 & 0 & 0.00 & 0 & 0.00 \\
\hline VICA & 25 & 100.00 & 0 & 0.00 & 0 & 0.00 & 0 & 0.00 & 0 & 0.00 & 0 & 0.00 \\
\hline FBLA & 25 & 100.00 & 0 & 0.00 & 0 & 0.00 & 0 & 0.00 & 0 & 0.00 & 0 & 0.00 \\
\hline SkillsUSA & 25 & 100.00 & 0 & 0.00 & 0 & 0.00 & 0 & 0.00 & 0 & 0.00 & 0 & 0.00 \\
\hline
\end{tabular}




\section{Participation in Activities Outside of High School}

Respondents were asked what activities they participated in outside of high school and what their highest level of participation using the responses of: did not participate, member, chapter officer, regional/district officer, state officer, or national officer. For Church Groups, one (3.03\%) reported not participating in a church group, $21(63.64 \%)$ were members, seven (21.21\%) participated as chapter officer, one $(3.03 \%)$ served as a regional/district officer, two $(6.06 \%)$ were state officers, and one $(3.03 \%)$ served as a national officer. In reference to scouts, $21(77.78 \%)$ respondents indicated they did not participate in scouts, four $(14.81 \%)$ were members, one $(3.70 \%)$ was a chapter officer, and one (3.70\%) was a state officer. For Junior Achievement, 24 (92.31\%) respondents did not participate in Junior Achievement, one (3.85\%) was a member, and one $(3.85 \%)$ was a chapter officer. There were eight $(27.59 \%)$ respondents who did not participate in 4-H, four (13.79\%) who were 4-H members, 15 (51.72\%) respondents who were 4-H chapter officers, one (3.45\%)individual who was a regional/district 4-H officer, and one (3.45\%) served as a state 4-H officer. Respondents were asked whether they held a job while in high school, five (16.13\%) respondents reported they did not have a job in high school, $21(67.74 \%)$ were members, one (3.23\%) was a regional/district officer, two $(6.45 \%)$ were state officers, and two $(6.45 \%)$ were a national officer. When asked about participation in Pageants, $22(88.00 \%)$ respondents did not participate in pageants, two $(8.00 \%)$ were members, and one $(4.00 \%)$ participated as a chapter officer. There were 13 (86.67\%) who did not participate in other activities, one (6.67\%) who was a member, and one $(6.67 \%)$ was a chapter officer. In JTPA there were no respondents (see Table 19). 
Table 19

Activities Participated in Outside of High School

\begin{tabular}{|c|c|c|c|c|c|c|c|c|c|c|c|c|}
\hline & \multicolumn{2}{|c|}{$\begin{array}{c}\text { Did Not } \\
\text { Participate }\end{array}$} & \multicolumn{2}{|c|}{ Member } & \multicolumn{2}{|c|}{ Chapter Officer } & \multicolumn{2}{|c|}{$\begin{array}{c}\text { Regional- } \\
\text { District Officer }\end{array}$} & \multicolumn{2}{|c|}{ State Officer } & \multicolumn{2}{|c|}{$\begin{array}{l}\text { National } \\
\text { Officer }\end{array}$} \\
\hline & $\mathrm{N}$ & $\%$ & $\mathrm{~N}$ & $\%$ & $\mathrm{~N}$ & $\%$ & $\mathrm{~N}$ & $\%$ & $\mathrm{~N}$ & $\%$ & $\mathrm{~N}$ & $\%$ \\
\hline Church Groups & 1 & 3.03 & 21 & 63.64 & 7 & 21.21 & 1 & 3.03 & 2 & 6.06 & 1 & 3.03 \\
\hline Scouts & 21 & 77.78 & 4 & 14.81 & 1 & 3.70 & 0 & 0.00 & 1 & 3.70 & 0 & 0.00 \\
\hline Junior Achievement & 24 & 92.31 & 1 & 3.85 & 1 & 3.85 & 0 & 0.00 & 0 & 0.00 & 0 & 0.00 \\
\hline JTPA & 25 & 100.00 & 0 & 0.00 & 0 & 0.00 & 0 & 0.00 & 0 & 0.00 & 0 & 0.00 \\
\hline 4-H & 8 & 27.59 & 4 & 13.79 & 15 & 51.72 & 1 & 3.45 & 1 & 3.45 & 0 & 0.00 \\
\hline Job & 5 & 16.13 & 21 & 67.74 & 0 & 0.00 & 1 & 3.23 & 2 & 6.45 & 2 & 6.45 \\
\hline Pageants & 22 & 88.00 & 2 & 8.00 & 1 & 4.00 & 0 & 0.00 & 0 & 0.00 & 0 & 0.00 \\
\hline Other & 13 & 86.67 & 1 & 6.67 & 0 & 0.00 & 0 & 0.00 & 0 & 0.00 & 1 & 6.67 \\
\hline
\end{tabular}




\section{Activities Participated in College}

Respondents were asked what activities they participated in during college and what their highest level of participation was using the responses: did not participate, member, chapter officer, regional/district officer, state officer, or national officer. For university student council, $22(84.62 \%)$ reported not participating in university student council, one (3.85\%) was a member, two (7.69\%) participated as chapter officer, and one (3.85\%) was a state officers. In college student council, 18 (72.00\%) did not participate, two $(8.00 \%)$ were members, and five $(20.00 \%)$ were chapter officer. In club involvement, 11 (36.67\%) did not participate, eight (26.67\%) were members, eight (26.67\%) were chapter officer, and three $(10.00 \%)$ were state officers. There were $24(88.89 \%)$ who did not participate in sports, two $(7.41 \%)$ who were members, and one $(3.70 \%)$ who was a regional/district officer. The respondents were asked whether they were in a fraternity/sorority, $14(50.00 \%)$ did not participate, six (21.43\%) were members, six (21.43\%) were chapter officer, one (3.57\%) was a state officer, and one $(3.57 \%)$ was a national officer. In Band, $24(96.00 \%)$ did not participate, and one (4.00\%) was a member. There were 15 (68.18\%) who did not participate in other activities, five $(22.73 \%)$ who was a member, one $(4.55 \%)$ was a chapter officer, and one $(4.55 \%)$ was a state officer (see Table 20). 
Table 20

Activities Participated in College

\begin{tabular}{|c|c|c|c|c|c|c|c|c|c|c|c|c|}
\hline & \multicolumn{2}{|c|}{$\begin{array}{l}\text { Did Not } \\
\text { Participate }\end{array}$} & \multicolumn{2}{|c|}{ Member } & \multicolumn{2}{|c|}{$\begin{array}{l}\text { Chapter } \\
\text { Officer }\end{array}$} & \multicolumn{2}{|c|}{$\begin{array}{c}\text { Regional- } \\
\text { District Officer }\end{array}$} & \multicolumn{2}{|c|}{ State Officer } & \multicolumn{2}{|c|}{$\begin{array}{l}\text { National } \\
\text { Officer }\end{array}$} \\
\hline & $\mathrm{N}$ & $\%$ & $\mathrm{~N}$ & $\%$ & $\mathrm{~N}$ & $\%$ & $\mathrm{~N}$ & $\%$ & $\mathrm{~N}$ & $\%$ & $\mathrm{~N}$ & $\%$ \\
\hline University Student Council & 22 & 84.62 & 1 & 3.85 & 2 & 7.69 & 0 & 0.00 & 1 & 3.85 & 0 & 0.00 \\
\hline College Student Council & 18 & 72.00 & 2 & 8.00 & 5 & 20.00 & 0 & 0.00 & 0 & 0.00 & 0 & 0.00 \\
\hline Sports & 24 & 88.89 & 2 & 7.41 & 0 & 0.00 & 1 & 3.70 & 0 & 0.00 & 0 & 0.00 \\
\hline Fraternity/ Sorority & 14 & 50.00 & 6 & 21.43 & 6 & 21.43 & 0 & 0.00 & 1 & 3.57 & 1 & 3.57 \\
\hline Band & 24 & 96.00 & 1 & 4.00 & 0 & 0.00 & 0 & 0.00 & 0 & 0.00 & 0 & 0.00 \\
\hline
\end{tabular}




\section{Leadership Traits}

Participants were asked about various leadership traits and their own abilities and how FFA influenced those traits. When asked to rate how they were at determining their personal needs, two reported they were "average" at determining needs with one $(50.00 \%)$ of them replying FFA was "somewhat influential," and the one $(50.00 \%)$ replying that FFA was "very influential." Of the 14 respondents who reported they were "good" at determining need, one (7.14\%) reported FFA was "not at all influential," one (7.14\%) reported FFA was "slightly influential," four (28.57\%) reported FFA was "somewhat influential," five (35.71\%) indicated FFA was "very influential," and three $(21.43 \%)$ indicating it was "extremely influential." Of the respondents 17 indicated they were "excellent" at determining needs with one (5.88\%) replying FFA was "not at all influential," two (11.76\%) replying it was "slightly influential," two (11.76\%) responding it was "somewhat influential," eight (47.06\%) indicating it was "very influential," and four $(23.53 \%)$ replying it was “extremely influential.” None of the respondents replied they were "very poor" or "poor" at determining needs (see Table 21). 
Table 21

Ability to Determine Personal Needs and FFA's Influence

\begin{tabular}{lcccccccccc}
\hline & \multicolumn{2}{c}{ Very Poor } & \multicolumn{2}{c}{ Poor } & \multicolumn{2}{c}{ Average } & \multicolumn{2}{c}{ Good } & \multicolumn{2}{c}{ Excellent } \\
\cline { 2 - 10 } & $\mathrm{N}$ & $\%$ & $\mathrm{~N}$ & $\%$ & $\mathrm{~N}$ & $\%$ & $\mathrm{~N}$ & $\%$ & $\mathrm{~N}$ & $\%$ \\
\hline $\begin{array}{l}\text { Not at all } \\
\text { Influential }\end{array}$ & 0 & 0.00 & 0 & 0.00 & 0 & 0.00 & 1 & 7.14 & 1 & 5.88 \\
$\begin{array}{l}\text { Slightly } \\
\text { Influential }\end{array}$ & 0 & 0.00 & 0 & 0.00 & 0 & 0.00 & 1 & 7.14 & 2 & 11.76 \\
$\begin{array}{l}\text { Somewhat } \\
\text { Influential }\end{array}$ & 0 & 0.00 & 0 & 0.00 & 1 & 50.00 & 4 & 28.57 & 2 & 11.76 \\
$\begin{array}{l}\text { Very } \\
\text { Influential }\end{array}$ & 0 & 0.00 & 0 & 0.00 & 1 & 50.00 & 5 & 35.71 & 8 & 47.06 \\
$\begin{array}{l}\text { Extremely } \\
\text { Influential }\end{array}$ & 0 & 0.00 & 0 & 0.00 & 0 & 0.00 & 3 & 21.43 & 4 & 23.53 \\
\hline
\end{tabular}

Participants were asked if they had a positive self-concept and what FFA's influence was on development. There were three participants who responded they had an "average" positive self-concept, of those one (33.33\%) indicated FFA was "somewhat influential," one (33.33\%) stated that FFA was "very influential," and one (33.33\%) who rated FFA as "extremely influential," in their development of self-concept. There were 15 participants who rated their self-concept as "good," one (6.67\%) respondent reported FFA was "slightly influential," in their development, two (13.33\%) indicated FFA was “somewhat influential," six (40.00\%) reported FFA was "very influential," and six (40.00\%) responding FFA was "extremely influential." Of the 15 participants who rated FFA “excellent” two (13.33\%) responded FFA was “somewhat influential." Six (40.00\%) replied FFA was "very influential," and seven (46.67\%) specified FFA was "extremely 
influential." None of the participants rated their positive self-concept as "very poor" or “poor” (see Table 22).

Table 22

Have a Positive Self-Concept and FFA's Influence

\begin{tabular}{lcccccccccc}
\hline & \multicolumn{2}{c}{ Very Poor } & \multicolumn{2}{c}{ Poor } & \multicolumn{2}{c}{ Average } & \multicolumn{2}{c}{ Good } & \multicolumn{2}{c}{ Excellent } \\
\cline { 2 - 10 } & $\mathrm{N}$ & $\%$ & $\mathrm{~N}$ & $\%$ & $\mathrm{~N}$ & $\%$ & $\mathrm{~N}$ & $\%$ & $\mathrm{~N}$ & $\%$ \\
\hline $\begin{array}{l}\text { Not at all } \\
\text { Influential }\end{array}$ & 0 & 0.00 & 0 & 0.00 & 0 & 0.00 & 0 & 0.00 & 0 & 0.00 \\
$\begin{array}{l}\text { Slightly } \\
\text { Influential }\end{array}$ & 0 & 0.00 & 0 & 0.00 & 0 & 0.00 & 1 & 6.67 & 0 & 0.00 \\
$\begin{array}{l}\text { Somewhat } \\
\text { Influential }\end{array}$ & 0 & 0.00 & 0 & 0.00 & 1 & 33.33 & 2 & 13.33 & 2 & 13.33 \\
$\begin{array}{l}\text { Very } \\
\text { Influential }\end{array}$ & 0 & 0.00 & 0 & 0.00 & 1 & 33.33 & 6 & 40.00 & 6 & 40.00 \\
$\begin{array}{l}\text { Extremely } \\
\text { Influential }\end{array}$ & 0 & 0.00 & 0 & 0.00 & 1 & 33.33 & 6 & 40.00 & 7 & 46.67 \\
\hline
\end{tabular}

When the respondents were asked if they are able to express their feelings and FFA's influence there were 35 responses. There were seven participants who rated their ability "average" with five (71.43\%) responding FFA was "somewhat influential," and two $(28.57 \%)$ responding FFA was "very influential." There were 15 participants who rated themselves as "good" at expressing their feelings with one (6.67\%) indicating FFA was "not at all influential," four (26.67\%) indicating FFA was "slightly influential," two (13.33\%) responded FFA was "somewhat influential," seven (46.67\%) responded FFA being "very influential," and one (6.67\%) responding FFA was "extremely influential." Of the 11 participants who rated FFA "excellent" one (9.09\%) specified FFA was 
"slightly influential," five (45.45\%) indicated FFA was "very influential," and five (45.45\%) replied FFA was "extremely influential." None of the participants rated their ability to express feelings as "very poor" or "poor" (see Table 23).

Table 23

Ability to Express Feelings and FFA's Influence

\begin{tabular}{lcccccccccc}
\hline & \multicolumn{2}{c}{ Very Poor } & \multicolumn{2}{c}{ Poor } & \multicolumn{2}{c}{ Average } & \multicolumn{2}{c}{ Good } & \multicolumn{2}{c}{ Excellent } \\
\cline { 2 - 10 } & $\mathrm{N}$ & $\%$ & $\mathrm{~N}$ & $\%$ & $\mathrm{~N}$ & $\%$ & $\mathrm{~N}$ & $\%$ & $\mathrm{~N}$ & $\%$ \\
\hline $\begin{array}{l}\text { Not at all } \\
\text { Influential }\end{array}$ & 0 & 0.00 & 0 & 0.00 & 0 & 0.00 & 1 & 6.67 & 0 & 0.00 \\
$\begin{array}{l}\text { Slightly } \\
\text { Influential }\end{array}$ & 0 & 0.00 & 0 & 0.00 & 0 & 0.00 & 4 & 26.67 & 1 & 9.09 \\
$\begin{array}{l}\text { Somewhat } \\
\text { Influential }\end{array}$ & 0 & 0.00 & 0 & 0.00 & 5 & 71.43 & 2 & 13.33 & 0 & 0.00 \\
$\begin{array}{l}\text { Very } \\
\text { Influential }\end{array}$ & 0 & 0.00 & 0 & 0.00 & 2 & 28.57 & 7 & 46.67 & 5 & 45.45 \\
$\begin{array}{l}\text { Extremely } \\
\text { Influential }\end{array}$ & 0 & 0.00 & 0 & 0.00 & 0 & 0.00 & 1 & 6.67 & 5 & 45.45 \\
\hline
\end{tabular}

When the respondents were asked if they can set personal goals and what FFA's influence was, one (100.00\%) respondent replied they were "average" at determining needs replying FFA was "extremely influential." Of the 18 respondents who responded they were "good" at setting personal goals two (11.11\%) replied FFA was "slightly influential," six (33.33\%) designated FFA was "somewhat influential," five (27.78\%) specified FFA was "very influential," and five (27.78\%) replying FFA was "extremely influential." Of the respondents 15 indicated they were "excellent" at setting personal goals with two (13.33\%) responding FFA was "somewhat influential," four (26.67\%) 
replying FFA was "very influential," and nine (60.00\%) indicating FFA was "extremely influential." No respondents indicated they were "very poor" or "poor" at setting personal goals (see Table 24)

Table 24

Ability to Set Personal Goals and FFA's Influence

\begin{tabular}{lcccccccccc}
\hline & \multicolumn{2}{l}{ Very Poor } & \multicolumn{2}{c}{ Poor } & \multicolumn{2}{c}{ Average } & \multicolumn{2}{c}{ Good } & \multicolumn{2}{c}{ Excellent } \\
\cline { 2 - 11 } & $\mathrm{N}$ & $\%$ & $\mathrm{~N}$ & $\%$ & $\mathrm{~N}$ & $\%$ & $\mathrm{~N}$ & $\%$ & $\mathrm{~N}$ & $\%$ \\
\hline $\begin{array}{l}\text { Not at all } \\
\text { Influential }\end{array}$ & 0 & 0.00 & 0 & 0.00 & 0 & 0.00 & 0 & 0.00 & 0 & 0.00 \\
$\begin{array}{l}\text { Slightly } \\
\text { Influential }\end{array}$ & 0 & 0.00 & 0 & 0.00 & 0 & 0.00 & 2 & 11.11 & 0 & 0.00 \\
$\begin{array}{l}\text { Somewhat } \\
\text { Influential }\end{array}$ & 0 & 0.00 & 0 & 0.00 & 0 & 0.00 & 6 & 33.33 & 2 & 13.33 \\
$\begin{array}{l}\text { Very } \\
\text { Influential }\end{array}$ & 0 & 0.00 & 0 & 0.00 & 0 & 0.00 & 5 & 27.78 & 4 & 26.67 \\
$\begin{array}{l}\text { Extremely } \\
\text { Influential }\end{array}$ & 0 & 0.00 & 0 & 0.00 & 1 & 100.00 & 5 & 27.78 & 9 & 60.00 \\
\hline
\end{tabular}

Participants were asked if they are able to set group goals and what FFA's influence was to which there were 34 responses. There were four participants answered they had an "average" ability to set group goals, two (50.00\%) responded FFA was "somewhat influential," one (25.00\%) stated FFA as "very influential," and one $(25.00 \%)$ who rated FFA “extremely influential." There were 15 participants who rated FFA “good," one (6.67\%) replied FFA was “slightly influential," four (26.67\%) responding that FFA was "somewhat influential," nine (60.00\%) responding FFA was "very influential," and one 6.67\%) indicating FFA was “extremely influential.” Of the 15 
participants who rated FFA "excellent" one (6.67\%) designated FFA was "slightly influential," one (6.67\%) replied FFA was "Somewhat Influential." Four (26.67\%) indicated FFA was "very influential," and nine (60.00\%) specified FFA was "Extremely Influential. None of the participants rated ability to set group goals as "very poor" or "poor" (see Table 25).

Table 25

Ability to Set Group Goals and FFA's Influence

\begin{tabular}{lcccccccccc}
\hline & \multicolumn{2}{c}{ Very Poor } & \multicolumn{2}{c}{ Poor } & \multicolumn{2}{c}{ Average } & \multicolumn{2}{c}{ Good } & \multicolumn{2}{c}{ Excellent } \\
\cline { 2 - 10 } & $\mathrm{N}$ & $\%$ & $\mathrm{~N}$ & $\%$ & $\mathrm{~N}$ & $\%$ & $\mathrm{~N}$ & $\%$ & $\mathrm{~N}$ & $\%$ \\
\hline $\begin{array}{l}\text { Not at all } \\
\text { Influential }\end{array}$ & 0 & 0.00 & 0 & 0.00 & 0 & 0.00 & 0 & 0.00 & 0 & 0.00 \\
$\begin{array}{l}\text { Slightly } \\
\text { Influential }\end{array}$ & 0 & 0.00 & 0 & 0.00 & 0 & 0.00 & 1 & 6.67 & 1 & 6.67 \\
$\begin{array}{l}\text { Somewhat } \\
\text { Influential }\end{array}$ & 0 & 0.00 & 0 & 0.00 & 2 & 50.00 & 4 & 26.67 & 1 & 6.67 \\
$\begin{array}{l}\text { Very } \\
\text { Influential }\end{array}$ & 0 & 0.00 & 0 & 0.00 & 1 & 25.00 & 9 & 60.00 & 4 & 26.67 \\
$\begin{array}{l}\text { Extremely } \\
\text { Influential }\end{array}$ & 0 & 0.00 & 0 & 0.00 & 1 & 25.00 & 1 & 6.67 & 9 & 60.00 \\
\hline
\end{tabular}

When the respondents were asked if they can be honest with others and what influence FFA had on their ability, there were 34 responses. There was one $(100.00 \%)$ respondent who rated FFA "average" indicating FFA was "somewhat influential." There were 12 respondents who rated themselves as "good" at being honest with others with one $(8.33 \%)$ responding FFA was "not at all influential," one (8.33\%) responding FFA was "slightly influential," three (25.00\%) responded FFA was "somewhat influential," 
five $(41.67 \%)$ responded FFA was "very influential," and two $(16.67 \%)$ responded FFA was "extremely influential.". Of the 21 participants who rated themselves "excellent" one (4.76\%) designated FFA state presidency was "not at all influential," four (19.05\%) replied FFA was “somewhat influential," five (23.81\%) rated FFA “very influential," and $11(52.38 \%)$ responded FFA was "Extremely Influential. None of the participants rated their ability to be honest with others as "very poor" or "poor" (see Table 26). Table 26

Ability to be Honest with Others and FFA's Influence

\begin{tabular}{lcccccccccc}
\hline & \multicolumn{2}{c}{ Very Poor } & \multicolumn{2}{c}{ Poor } & \multicolumn{2}{c}{ Average } & \multicolumn{2}{c}{ Good } & \multicolumn{2}{c}{ Excellent } \\
\cline { 2 - 9 } & $\mathrm{N}$ & $\%$ & $\mathrm{~N}$ & $\%$ & $\mathrm{~N}$ & $\%$ & $\mathrm{~N}$ & $\%$ & $\mathrm{~N}$ & $\%$ \\
\hline $\begin{array}{l}\text { Not at all } \\
\text { Influential }\end{array}$ & 0 & 0.00 & 0 & 0.00 & 0 & 0.00 & 1 & 8.33 & 1 & 4.76 \\
$\begin{array}{l}\text { Slightly } \\
\text { Influential }\end{array}$ & 0 & 0.00 & 0 & 0.00 & 0 & 0.00 & 1 & 8.33 & 0 & 0.00 \\
$\begin{array}{l}\text { Somewhat } \\
\text { Influential }\end{array}$ & 0 & 0.00 & 0 & 0.00 & 1 & 100.00 & 3 & 25.00 & 4 & 19.05 \\
$\begin{array}{l}\text { Very } \\
\text { Influential }\end{array}$ & 0 & 0.00 & 0 & 0.00 & 0 & 0.00 & 5 & 41.67 & 5 & 23.81 \\
$\begin{array}{l}\text { Extremely } \\
\text { Influential }\end{array}$ & 0 & 0.00 & 0 & 0.00 & 0 & 0.00 & 2 & 16.67 & 11 & 52.38 \\
\hline
\end{tabular}

Respondents were asked about the ability to use information to solve problems and the influence FFA had. There was one $(100.00 \%)$ respondent who rated FFA "average" indicating FFA was "somewhat influential." There were 13 respondents who rated themselves as "good" at being able to use information for problem solving with one (7.64\%) responding FFA was "slightly influential," four $(30.77 \%)$ responded FFA was 
“somewhat influential," six (46.15\%) responded FFA was "very influential," and two $(15.38 \%)$ responded FFA was “extremely influential.” Of the 20 respondents who rated themselves "excellent" three $(15.00 \%)$ responded FFA state presidency was "slightly influential," two (10.00\%) specified FFA was "somewhat influential," eight (40.00\%) rated FFA "very influential," and seven (35.00\%) designated FFA was "Extremely Influential. None of the respondents rated their ability to use information to solve problems as "very poor" or "poor" (see Table 27).

Table 27

Ability to Use Information to Solve Problems and FFA's Influence

\begin{tabular}{lcccccccccc}
\hline & \multicolumn{2}{l}{ Very Poor } & \multicolumn{2}{c}{ Poor } & \multicolumn{2}{c}{ Average } & \multicolumn{2}{c}{ Good } & \multicolumn{2}{c}{ Excellent } \\
\cline { 2 - 11 } & $\mathrm{N}$ & $\%$ & $\mathrm{~N}$ & $\%$ & $\mathrm{~N}$ & $\%$ & $\mathrm{~N}$ & $\%$ & $\mathrm{~N}$ & $\%$ \\
\hline $\begin{array}{l}\text { Not at all } \\
\text { Influential }\end{array}$ & 0 & 0.00 & 0 & 0.00 & 0 & 0.00 & 0 & 0.00 & 0 & 0.00 \\
$\begin{array}{l}\text { Slightly } \\
\text { Influential }\end{array}$ & 0 & 0.00 & 0 & 0.00 & 0 & 0.00 & 1 & 7.69 & 3 & 15.00 \\
$\begin{array}{l}\text { Somewhat } \\
\text { Influential }\end{array}$ & 0 & 0.00 & 0 & 0.00 & 1 & 100.00 & 4 & 30.77 & 2 & 10.00 \\
$\begin{array}{l}\text { Very } \\
\text { Influential }\end{array}$ & 0 & 0.00 & 0 & 0.00 & 0 & 0.00 & 6 & 46.15 & 8 & 40.00 \\
$\begin{array}{l}\text { Extremely } \\
\text { Influential }\end{array}$ & 0 & 0.00 & 0 & 0.00 & 0 & 0.00 & 2 & 15.38 & 7 & 35.00 \\
\hline
\end{tabular}

Participants were asked if they can delegate responsibility and how influential FFA was in the development. Of the participants, one (100.00\%) replied they were "poor" at delegating responsibility and the FFA was "somewhat influential." There were two (100.00\%) participants who rated FFA "average "responding FFA was "somewhat 
influential.". There were 18 participants who rated themselves as "good" at delegating responsibility with one (5.56\%) replying FFA was "not at all influential," two $(11.11 \%)$ indicating FFA was "slightly influential," one (5.56\%) responded FFA was "somewhat influential," $10(55.56 \%)$ responded FFA being "very influential," and four $(22.22 \%)$ responding FFA was "extremely influential." Of the 13 participants who rated themselves “excellent" one (7.69\%) indicated FFA was "slightly influential," one (7.69\%) replied FFA was "somewhat influential," five (38.46\%) responded FFA was "very influential," and six (46.15\%) specified FFA was "extremely influential." None of the participants rated their ability to delegate responsibility as "very poor" "poor," or "average" (see Table 28).

Table 28

Ability to Delegate Responsibility and FFA's Influence

\begin{tabular}{|c|c|c|c|c|c|c|c|c|c|c|}
\hline & \multicolumn{2}{|c|}{ Very Poor } & \multicolumn{2}{|c|}{ Poor } & \multicolumn{2}{|c|}{ Average } & \multicolumn{2}{|c|}{ Good } & \multicolumn{2}{|c|}{ Excellent } \\
\hline & $\mathrm{N}$ & $\%$ & $\mathrm{~N}$ & $\%$ & $\mathrm{~N}$ & $\%$ & $\mathrm{~N}$ & $\%$ & $\mathrm{~N}$ & $\%$ \\
\hline $\begin{array}{l}\text { Not at all } \\
\text { Influential }\end{array}$ & 0 & 0.00 & 0 & 0.00 & 0 & 0.00 & 1 & 5.56 & 0 & 0.00 \\
\hline $\begin{array}{l}\text { Slightly } \\
\text { Influential }\end{array}$ & 0 & 0.00 & 0 & 0.00 & 0 & 0.00 & 2 & 11.11 & 1 & 7.69 \\
\hline $\begin{array}{l}\text { Somewhat } \\
\text { Influential }\end{array}$ & 0 & 0.00 & 1 & 100.00 & 0 & 0.00 & 1 & 5.56 & 1 & 7.69 \\
\hline $\begin{array}{l}\text { Very } \\
\text { Influential }\end{array}$ & 0 & 0.00 & 0 & 0.00 & 2 & 100.00 & 10 & 55.56 & 5 & 38.46 \\
\hline $\begin{array}{l}\text { Extremely } \\
\text { Influential }\end{array}$ & 0 & 0.00 & 0 & 0.00 & 0 & 0.00 & 4 & 22.22 & 6 & 46.15 \\
\hline
\end{tabular}


Respondents were asked if they are able to set priorities and whether FFA influenced their ability. There were three participants who rated themselves "average" at being able to set priorities, with one (33.33\%) replying FFA was "somewhat influential," and two (66.66\%) replying FFA was "very influential." There were 11 participants who rated themselves as "good" at being flexible with one $(9.09 \%)$ indicating FFA was "not at all influential," two (18.18\%) replying FFA was "slightly influential," one (9.09\%) responded FFA was "somewhat influential," and seven (63.64\%) responded FFA was "very influential." Of the 20 participants who rated themselves "excellent" one $(5.00 \%)$ designated FFA state presidency was "slightly influential," five (25.00\%) replied FFA was "somewhat influential," four (20.00\%) rated FFA "very influential," and 10 $(50.00 \%)$ specified FFA was "extremely influential." None of the participants rated their ability to set priorities as "very poor" or "poor" (see Table 29).

Table 29

Ability to Set Priorities and FFA's Influence

\begin{tabular}{|c|c|c|c|c|c|c|c|c|c|c|}
\hline & \multicolumn{2}{|c|}{ Very Poor } & \multicolumn{2}{|c|}{ Poor } & \multicolumn{2}{|c|}{ Average } & \multicolumn{2}{|c|}{ Good } & \multicolumn{2}{|c|}{ Excellent } \\
\hline & $\mathrm{N}$ & $\%$ & $\mathrm{~N}$ & $\%$ & $\mathrm{~N}$ & $\%$ & $\mathrm{~N}$ & $\%$ & $\mathrm{~N}$ & $\%$ \\
\hline $\begin{array}{l}\text { Not at all } \\
\text { Influential }\end{array}$ & 0 & 0.00 & 0 & 0.00 & 0 & 0.00 & 1 & 9.09 & 0 & 0.00 \\
\hline $\begin{array}{l}\text { Slightly } \\
\text { Influential }\end{array}$ & 0 & 0.00 & 0 & 0.00 & 0 & 0.00 & 2 & 18.18 & 1 & 5.00 \\
\hline $\begin{array}{l}\text { Somewhat } \\
\text { Influential }\end{array}$ & 0 & 0.00 & 0 & 0.00 & 1 & 33.33 & 1 & 9.09 & 5 & 25.00 \\
\hline $\begin{array}{l}\text { Very } \\
\text { Influential }\end{array}$ & 0 & 0.00 & 0 & 0.00 & 2 & 66.66 & 7 & 63.64 & 4 & 20.00 \\
\hline $\begin{array}{l}\text { Extremely } \\
\text { Influential }\end{array}$ & 0 & 0.00 & 0 & 0.00 & 0 & 0.00 & 0 & 0.00 & 10 & 50.00 \\
\hline
\end{tabular}


Participants were asked if they are sensitive to others and what influence FFA played on the ability. There were two participants who rated themselves as "average" with one (50.00\%) responding FFA was "somewhat influential," and one (50.00\%) indicating FFA was "very influential." There were 17 participants who rated themselves as "good" at being flexible with two (11.76\%) responding FFA was "not at all influential," one (5.88\%) indicating FFA was "slightly influential," six (35.29\%) responded FFA was "somewhat influential," seven (41.18\%) responded FFA was "very influential," and one (5.88\%) responded FFA was "extremely influential." Of the 15 participants who rated themselves "excellent" one (6.67\%) indicated FFA state presidency was "slightly influential," four (26.67\%) designated FFA was "somewhat influential," four (26.67\%) rated FFA "very influential," and six (40.00\%) replied FFA was "extremely influential." None of the participants rated their ability as "very poor" or “poor” (see Table 30). 
Table 30

Sensitivity to Others and FFA's Influence

\begin{tabular}{|c|c|c|c|c|c|c|c|c|c|c|}
\hline & \multicolumn{2}{|c|}{ Very Poor } & \multicolumn{2}{|c|}{ Poor } & \multicolumn{2}{|c|}{ Average } & \multicolumn{2}{|c|}{ Good } & \multicolumn{2}{|c|}{ Excellent } \\
\hline & $\mathrm{N}$ & $\%$ & $\mathrm{~N}$ & $\%$ & $\mathrm{~N}$ & $\%$ & $\mathrm{~N}$ & $\%$ & $\mathrm{~N}$ & $\%$ \\
\hline $\begin{array}{l}\text { Not at all } \\
\text { Influential }\end{array}$ & 0 & 0.00 & 0 & 0.00 & 0 & 0.00 & 2 & 11.76 & 0 & 0.00 \\
\hline $\begin{array}{l}\text { Slightly } \\
\text { Influential }\end{array}$ & 0 & 0.00 & 0 & 0.00 & 0 & 0.00 & 1 & 5.88 & 1 & 6.67 \\
\hline $\begin{array}{l}\text { Somewhat } \\
\text { Influential }\end{array}$ & 0 & 0.00 & 0 & 0.00 & 1 & 50.00 & 6 & 35.29 & 4 & 26.67 \\
\hline $\begin{array}{l}\text { Very } \\
\text { Influential }\end{array}$ & 0 & 0.00 & 0 & 0.00 & 1 & 50.00 & 7 & 41.18 & 4 & 26.67 \\
\hline $\begin{array}{l}\text { Extremely } \\
\text { Influential }\end{array}$ & 0 & 0.00 & 0 & 0.00 & 0 & 0.00 & 1 & 5.88 & 6 & 40.00 \\
\hline
\end{tabular}

Respondents were asked about their sense of being open minded and how FFA influenced their sense. There were two participants who rated themselves "average" with one $(50.00 \%)$ responding FFA was "somewhat influential," and one $(50.00 \%)$ indicating FFA was "very influential." There were 17 participants who rated themselves as "good" at express their feelings with one (5.88\%) indicating FFA was "not at all influential," two $(11.76 \%)$ responding FFA was "slightly influential," five (29.41\%) responded FFA was “somewhat influential," and nine (52.94\%) responded FFA being "very influential.". Of the 15 participants who rated FFA "excellent" one (6.67\%) designated FFA was "slightly influential," five (33.33\%) responded FFA was "somewhat influential," three $(20.00 \%)$ rated FFA “very influential," and six (40.00\%) specified FFA was “extremely 
influential." None of the participants rated their sense of being open minded as "very poor" or "poor" (see Table 31).

Table 31

Respondent's Sense of Being Open Minded and FFA's Influence

\begin{tabular}{lcccccccccc}
\hline & \multicolumn{2}{c}{ Very Poor } & \multicolumn{2}{c}{ Poor } & \multicolumn{2}{c}{ Average } & \multicolumn{2}{c}{ Good } & \multicolumn{2}{c}{ Excellent } \\
\cline { 2 - 10 } & $\mathrm{N}$ & $\%$ & $\mathrm{~N}$ & $\%$ & $\mathrm{~N}$ & $\%$ & $\mathrm{~N}$ & $\%$ & $\mathrm{~N}$ & $\%$ \\
\hline $\begin{array}{l}\text { Not at all } \\
\text { Influential }\end{array}$ & 0 & 0.00 & 0 & 0.00 & 0 & 0.00 & 1 & 5.88 & 0 & 0.00 \\
$\begin{array}{l}\text { Slightly } \\
\text { Influential }\end{array}$ & 0 & 0.00 & 0 & 0.00 & 0 & 0.00 & 2 & 11.76 & 1 & 6.67 \\
$\begin{array}{l}\text { Somewhat } \\
\text { Influential }\end{array}$ & 0 & 0.00 & 0 & 0.00 & 1 & 50.00 & 5 & 29.41 & 5 & 33.33 \\
$\begin{array}{l}\text { Very } \\
\text { Influential }\end{array}$ & 0 & 0.00 & 0 & 0.00 & 1 & 50.00 & 9 & 52.94 & 3 & 20.00 \\
$\begin{array}{l}\text { Extremely } \\
\text { Influential }\end{array}$ & 0 & 0.00 & 0 & 0.00 & 0 & 0.00 & 0 & 0.00 & 6 & 40.00 \\
\hline
\end{tabular}

The respondents were asked how they rate their ability to consider the needs of others and how FFA influenced their ability. There were 13 respondents who rated their ability "good" five (38.46\%) responding FFA was "somewhat influential," seven (53.85\%) responding FFA was "very influential," and one (7.69\%) indicating FFA was "extremely influential." Of the 20 respondents who rated FFA "excellent" one (5.00\%) responded FFA was "slightly influential," six (30.00\%) indicated FFA was "somewhat influential," five (25.00\%) replied FFA was "very influential," and eight (40.00\%) designated FFA was "extremely influential." None of the respondents rated their ability to consider the needs of others as "very poor," "poor," or "average" (see Table 32). 
Table 32

Consideration for the Needs of Others and FFA's Influence

\begin{tabular}{lcccccccccc}
\hline & \multicolumn{2}{c}{ Very Poor } & \multicolumn{2}{c}{ Poor } & \multicolumn{2}{c}{ Average } & \multicolumn{2}{c}{ Good } & \multicolumn{2}{c}{ Excellent } \\
\cline { 2 - 10 } & $\mathrm{N}$ & $\%$ & $\mathrm{~N}$ & $\%$ & $\mathrm{~N}$ & $\%$ & $\mathrm{~N}$ & $\%$ & $\mathrm{~N}$ & $\%$ \\
\hline $\begin{array}{l}\text { Not at all } \\
\text { Influential }\end{array}$ & 0 & 0.00 & 0 & 0.00 & 0 & 0.00 & 0 & 0.00 & 0 & 0.00 \\
$\begin{array}{l}\text { Slightly } \\
\text { Influential }\end{array}$ & 0 & 0.00 & 0 & 0.00 & 0 & 0.00 & 0 & 0.00 & 1 & 5.00 \\
$\begin{array}{l}\text { Somewhat } \\
\text { Influential }\end{array}$ & 0 & 0.00 & 0 & 0.00 & 0 & 0.00 & 5 & 38.46 & 6 & 30.00 \\
$\begin{array}{l}\text { Very } \\
\text { Influential }\end{array}$ & 0 & 0.00 & 0 & 0.00 & 0 & 0.00 & 7 & 53.85 & 5 & 25.00 \\
$\begin{array}{l}\text { Extremely } \\
\text { Influential }\end{array}$ & 0 & 0.00 & 0 & 0.00 & 0 & 0.00 & 1 & 7.69 & 8 & 40.00 \\
\hline
\end{tabular}

Participants were asked their ability to show a responsible attitude and what influence FFA had on their ability. There were 11 participants who rated their ability "good," one (9.09\%) replied FFA was "slightly influential," three (27.27\%) calling is “somewhat influential," six (54.55\%) indicating FFA was "very influential," and one (9.09\%) acknowledged FFA was "extremely influential.” Of the 23 participants who rated their ability to show a responsible attitude "excellent," one (4.35\%) replied FFA was "slightly influential," three (13.04\%) responded FFA was "somewhat influential," five $(21.74 \%)$ indicated FFA was "very influential," and 14 (60.87\%) indicated FFA was "Extremely Influential. None of the participants rated their ability to show a responsible attitude as "very poor" "poor," or "average" (see Table 33). 
Table 33

Ability to Show a Responsible Attitude and FFA's Influence

\begin{tabular}{lcccccccccc}
\hline & \multicolumn{2}{c}{ Very Poor } & \multicolumn{2}{c}{ Poor } & \multicolumn{2}{c}{ Average } & \multicolumn{2}{c}{ Good } & \multicolumn{2}{c}{ Excellent } \\
\cline { 2 - 10 } & $\mathrm{N}$ & $\%$ & $\mathrm{~N}$ & $\%$ & $\mathrm{~N}$ & $\%$ & $\mathrm{~N}$ & $\%$ & $\mathrm{~N}$ & $\%$ \\
\hline $\begin{array}{l}\text { Not at all } \\
\text { Influential }\end{array}$ & 0 & 0.00 & 0 & 0.00 & 0 & 0.00 & 0 & 0.00 & 0 & 0.00 \\
$\begin{array}{l}\text { Slightly } \\
\text { Influential }\end{array}$ & 0 & 0.00 & 0 & 0.00 & 0 & 0.00 & 1 & 9.09 & 1 & 4.35 \\
$\begin{array}{l}\text { Somewhat } \\
\text { Influential }\end{array}$ & 0 & 0.00 & 0 & 0.00 & 0 & 0.00 & 3 & 27.27 & 3 & 13.04 \\
$\begin{array}{l}\text { Very } \\
\text { Influential }\end{array}$ & 0 & 0.00 & 0 & 0.00 & 0 & 0.00 & 6 & 54.55 & 5 & 21.74 \\
$\begin{array}{l}\text { Extremely } \\
\text { Influential }\end{array}$ & 0 & 0.00 & 0 & 0.00 & 0 & 0.00 & 1 & 9.09 & 14 & 60.87 \\
\hline
\end{tabular}

Participants were asked if they have a friendly personality and what FFA's influence was on their friendly personality. There were two $(100.00 \%)$ participants who rated their ability "average" with both replying FFA was "somewhat influential." There were 14 participants who rated themselves as "good" at being having a friendly personality with one (7.14\%) indicating FFA was "not at all influential," one (7.14\%) responding FFA was "slightly influential," four (28.57\%) responded FFA was "somewhat influential," five $(35.71 \%)$ responded FFA was "very influential," and three $(31.43 \%)$ replied FFA was "extremely influential." Of the 18 participants who rated themselves “excellent" two (11.11\%) replied state presidency FFA was "somewhat influential," eight (44.44\%) rated FFA "very influential," and eight (44.44\%) indicated FFA was 
"extremely influential." None of the participants rated their friendly personality as "very poor" or "poor" (see Table 34).

Table 34

Having a Friendly Personality and FFA's Influence on Personality

\begin{tabular}{lcccccccccc}
\hline & \multicolumn{2}{c}{ Very Poor } & \multicolumn{2}{c}{ Poor } & \multicolumn{2}{c}{ Average } & \multicolumn{2}{c}{ Good } & \multicolumn{2}{c}{ Excellent } \\
\cline { 2 - 10 } & $\mathrm{N}$ & $\%$ & $\mathrm{~N}$ & $\%$ & $\mathrm{~N}$ & $\%$ & $\mathrm{~N}$ & $\%$ & $\mathrm{~N}$ & $\%$ \\
\hline $\begin{array}{l}\text { Not at all } \\
\text { Influential }\end{array}$ & 0 & 0.00 & 0 & 0.00 & 0 & 0.00 & 1 & 7.14 & 0 & 0.00 \\
$\begin{array}{l}\text { Slightly } \\
\text { Influential }\end{array}$ & 0 & 0.00 & 0 & 0.00 & 0 & 0.00 & 1 & 7.14 & 0 & 0.00 \\
$\begin{array}{l}\text { Somewhat } \\
\text { Influential }\end{array}$ & 0 & 0.00 & 0 & 0.00 & 2 & 100.00 & 4 & 28.57 & 2 & 11.11 \\
$\begin{array}{l}\text { Very } \\
\text { Influential }\end{array}$ & 0 & 0.00 & 0 & 0.00 & 0 & 0.00 & 5 & 35.71 & 8 & 44.44 \\
$\begin{array}{l}\text { Extremely } \\
\text { Influential }\end{array}$ & 0 & 0.00 & 0 & 0.00 & 0 & 0.00 & 3 & 21.43 & 8 & 44.44 \\
\hline
\end{tabular}

Respondents were asked about their ability to consider input from all group members and FFA's influence. There were 22 respondents who rated themselves "good," two $(9.09 \%)$ rating FFA "slightly influential," two $(9.09 \%)$ calling FFA "somewhat influential," 15 (68.18\%) indicating FFA was "very influential," and three (13.64\%) indicating FFA was "extremely influential." Of the 13 respondents who rated themselves “excellent," one (7.69\%) specified FFA was "slightly influential," three (23.08\%) replied FFA was "somewhat influential," three (23.08\%) designated FFA was "very influential," and six (46.15\%) responded FFA was "extremely influential." None of the respondents 
rated their ability to consider input from all group members as "very poor," "poor," or “average" (see Table 35).

Table 35

Considers Input from All Group Members and FFA's Influence

\begin{tabular}{|c|c|c|c|c|c|c|c|c|c|c|}
\hline & \multicolumn{2}{|c|}{ Very Poor } & \multicolumn{2}{|c|}{ Poor } & \multicolumn{2}{|c|}{ Average } & \multicolumn{2}{|c|}{ Good } & \multicolumn{2}{|c|}{ Excellent } \\
\hline & $\mathrm{N}$ & $\%$ & $\mathrm{~N}$ & $\%$ & $\mathrm{~N}$ & $\%$ & $\mathrm{~N}$ & $\%$ & $\mathrm{~N}$ & $\%$ \\
\hline $\begin{array}{l}\text { Not at all } \\
\text { Influential }\end{array}$ & 0 & 0.00 & 0 & 0.00 & 0 & 0.00 & 0 & 0.00 & 0 & 0.00 \\
\hline $\begin{array}{l}\text { Slightly } \\
\text { Influential }\end{array}$ & 0 & 0.00 & 0 & 0.00 & 0 & 0.00 & 2 & 9.09 & 1 & 7.69 \\
\hline $\begin{array}{l}\text { Somewhat } \\
\text { Influential }\end{array}$ & 0 & 0.00 & 0 & 0.00 & 0 & 0.00 & 2 & 9.09 & 3 & 23.08 \\
\hline $\begin{array}{l}\text { Very } \\
\text { Influential }\end{array}$ & 0 & 0.00 & 0 & 0.00 & 0 & 0.00 & 15 & 68.18 & 3 & 23.08 \\
\hline $\begin{array}{l}\text { Extremely } \\
\text { Influential }\end{array}$ & 0 & 0.00 & 0 & 0.00 & 0 & 0.00 & 3 & 13.64 & 6 & 46.15 \\
\hline
\end{tabular}

The respondents were asked if they have the ability to listen effectively and FFA's influence, two (100.00\%) respondents specified they were "average" at listening effectively indicating FFA was "very influential". Of the 20 respondents who replied they were "good" at listening effectively, two (10.00\%) indicated FFA was "slightly influential," five (25.00\%) designated FFA was "somewhat influential," 10 (50.00\%) indicated FFA was "very influential," and three (15.00\%) replying FFA was "extremely influential." Of the respondents, 13 replied they were "excellent" at setting listening effectively with four $(30.77 \%)$ replying FFA was "somewhat influential," three $(23.08 \%)$ indicating FFA was "very influential," and six (46.15\%) indicating FFA was "extremely 
influential." No respondents specified they were "very poor" or "poor" at listening effectively (see Table 36).

Table 36

Ability to Listen Effectively and FFA's Influence

\begin{tabular}{lcccccccccc}
\hline & \multicolumn{2}{c}{ Very Poor } & \multicolumn{2}{c}{ Poor } & \multicolumn{2}{c}{ Average } & \multicolumn{2}{c}{ Good } & \multicolumn{2}{c}{ Excellent } \\
\cline { 2 - 10 } & $\mathrm{N}$ & $\%$ & $\mathrm{~N}$ & $\%$ & $\mathrm{~N}$ & $\%$ & $\mathrm{~N}$ & $\%$ & $\mathrm{~N}$ & $\%$ \\
\hline $\begin{array}{l}\text { Not at all } \\
\text { Influential }\end{array}$ & 0 & 0.00 & 0 & 0.00 & 0 & 0.00 & 0 & 0.00 & 0 & 0.00 \\
$\begin{array}{l}\text { Slightly } \\
\text { Influential }\end{array}$ & 0 & 0.00 & 0 & 0.00 & 0 & 0.00 & 2 & 10.00 & 0 & 0.00 \\
$\begin{array}{l}\text { Somewhat } \\
\text { Influential }\end{array}$ & 0 & 0.00 & 0 & 0.00 & 0 & 0.00 & 5 & 25.00 & 4 & 30.77 \\
$\begin{array}{l}\text { Very } \\
\text { Influential }\end{array}$ & 0 & 0.00 & 0 & 0.00 & 2 & 100.00 & 10 & 50.00 & 3 & 23.08 \\
$\begin{array}{l}\text { Extremely } \\
\text { Influential }\end{array}$ & 0 & 0.00 & 0 & 0.00 & 0 & 0.00 & 3 & 15.00 & 6 & 46.15 \\
\hline
\end{tabular}

Participants were asked if they are able to select alternatives and what FFA's influence was on their ability. There were two $(100.00 \%)$ participants who rated their ability "average" both indicating FFA was "very influential." There were 21 participants who rated themselves as "good" at being able to select alternatives with two (9.52\%) indicating FFA was "not at all influential," five (23.81\%) responded FFA was "somewhat influential," 12 (57.14\%) responded FFA was "very influential," and two (9.52\%) designated FFA was "extremely influential." Of the 11 participants who rated themselves "excellent" one (9.09\%) responded FFA state presidency was "slightly influential," four (36.36\%) indicated FFA was "somewhat influential," three (27.27\%) rated FFA "very 
influential," and three (27.27\%) replied FFA was "extremely influential." None of the participants rated their ability to select alternatives as "very poor" or "poor" (see Table 37).

Table 37

Ability to Select Alternatives and FFA's Influence

\begin{tabular}{lcccccccccc}
\hline & \multicolumn{2}{c}{ Very Poor } & \multicolumn{2}{c}{ Poor } & \multicolumn{2}{c}{ Average } & \multicolumn{2}{c}{ Good } & \multicolumn{2}{c}{ Excellent } \\
\cline { 2 - 10 } & $\mathrm{N}$ & $\%$ & $\mathrm{~N}$ & $\%$ & $\mathrm{~N}$ & $\%$ & $\mathrm{~N}$ & $\%$ & $\mathrm{~N}$ & $\%$ \\
\hline $\begin{array}{l}\text { Not at all } \\
\text { Influential }\end{array}$ & 0 & 0.00 & 0 & 0.00 & 0 & 0.00 & 2 & 9.52 & 0 & 0.00 \\
$\begin{array}{l}\text { Slightly } \\
\text { Influential }\end{array}$ & 0 & 0.00 & 0 & 0.00 & 0 & 0.00 & 0 & 0.00 & 1 & 9.09 \\
$\begin{array}{l}\text { Somewhat } \\
\text { Influential }\end{array}$ & 0 & 0.00 & 0 & 0.00 & 0 & 0.00 & 5 & 23.81 & 4 & 36.36 \\
$\begin{array}{l}\text { Very } \\
\text { Influential }\end{array}$ & 0 & 0.00 & 0 & 0.00 & 2 & 100.00 & 12 & 57.14 & 3 & 27.27 \\
$\begin{array}{l}\text { Extremely } \\
\text { Influential }\end{array}$ & 0 & 0.00 & 0 & 0.00 & 0 & 0.00 & 2 & 9.52 & 3 & 27.27 \\
\hline
\end{tabular}

Respondents were asked if they respect others and what influence FFA had on their ability. There were 10 respondents who rated their capability "good," one (10.00\%) calling FFA "somewhat influential," six (60.00\%) responding FFA was "very influential," and three (30.00\%) replying FFA was "extremely influential." Of the 25 respondents who rated their capability "excellent" one (4.00\%) replied FFA was "not at all influential," one (4.00\%) indicated FFA was "slightly influential," five (20.00\%) responded FFA was "somewhat influential," four (16.00\%) specified FFA was "very influential," and 14 (56.00\%) replied FFA was "extremely influential." None of the 
respondents rated their ability to respect others as "very poor," "poor," or "average" (see Table 38).

Table 38

Respect Others and FFA's Influence

\begin{tabular}{lcccccccccc}
\hline & \multicolumn{1}{c}{ Very Poor } & \multicolumn{2}{c}{ Poor } & \multicolumn{2}{c}{ Average } & \multicolumn{2}{c}{ Good } & \multicolumn{2}{c}{ Excellent } \\
\cline { 2 - 10 } & $\mathrm{N}$ & $\%$ & $\mathrm{~N}$ & $\%$ & $\mathrm{~N}$ & $\%$ & $\mathrm{~N}$ & $\%$ & $\mathrm{~N}$ & $\%$ \\
\hline $\begin{array}{l}\text { Not at all } \\
\text { Influential }\end{array}$ & 0 & 0.00 & 0 & 0.00 & 0 & 0.00 & 0 & 0.00 & 1 & 4.00 \\
$\begin{array}{l}\text { Slightly } \\
\text { Influential }\end{array}$ & 0 & 0.00 & 0 & 0.00 & 0 & 0.00 & 0 & 0.00 & 1 & 4.00 \\
$\begin{array}{l}\text { Somewhat } \\
\text { Influential }\end{array}$ & 0 & 0.00 & 0 & 0.00 & 0 & 0.00 & 1 & 10.00 & 5 & 20.00 \\
$\begin{array}{l}\text { Very } \\
\text { Influential }\end{array}$ & 0 & 0.00 & 0 & 0.00 & 0 & 0.00 & 6 & 60.00 & 4 & 16.00 \\
$\begin{array}{l}\text { Extremely } \\
\text { Influential }\end{array}$ & 0 & 0.00 & 0 & 0.00 & 0 & 0.00 & 3 & 30.00 & 14 & 56.00 \\
\hline
\end{tabular}

Participants were asked if they have the ability to solve problems and to what extent FFA influenced their ability. There were 14 participants who rated their ability "good," one (7.14\%) designated FFA was "slightly influential," five (35.71\%) calling FFA “somewhat influential," six (42.86\%) responding FFA was "very influential," and two (14.29\%) responding FFA was "extremely influential." Of the 20 participants who rated their ability "excellent" two (10.00\%) replied FFA was "slightly influential," five (25.00\%) responded FFA was "somewhat influential," six (30.00\%) replied FFA was "very influential," and seven (35.00\%) specified FFA was "extremely influential." None 
of the participants rated their ability to solve problems as "very poor," "poor," or “average” (see Table 39).

Table 39

Ability to Solve Problems and FFA's Influence

\begin{tabular}{lcccccccccc}
\hline & \multicolumn{2}{c}{ Very Poor } & \multicolumn{2}{c}{ Poor } & \multicolumn{2}{c}{ Average } & \multicolumn{2}{c}{ Good } & \multicolumn{2}{c}{ Excellent } \\
\cline { 2 - 9 } & $\mathrm{N}$ & $\%$ & $\mathrm{~N}$ & $\%$ & $\mathrm{~N}$ & $\%$ & $\mathrm{~N}$ & $\%$ & $\mathrm{~N}$ & $\%$ \\
\hline $\begin{array}{l}\text { Not at all } \\
\text { Influential }\end{array}$ & 0 & 0.00 & 0 & 0.00 & 0 & 0.00 & 0 & 0.00 & 0 & 0.00 \\
$\begin{array}{l}\text { Slightly } \\
\text { Influential }\end{array}$ & 0 & 0.00 & 0 & 0.00 & 0 & 0.00 & 1 & 7.14 & 2 & 10.00 \\
$\begin{array}{l}\text { Somewhat } \\
\text { Influential }\end{array}$ & 0 & 0.00 & 0 & 0.00 & 0 & 0.00 & 5 & 35.71 & 5 & 25.00 \\
$\begin{array}{l}\text { Very } \\
\text { Influential }\end{array}$ & 0 & 0.00 & 0 & 0.00 & 0 & 0.00 & 6 & 42.86 & 6 & 30.00 \\
$\begin{array}{l}\text { Extremely } \\
\text { Influential }\end{array}$ & 0 & 0.00 & 0 & 0.00 & 0 & 0.00 & 2 & 14.29 & 7 & 35.00 \\
\hline
\end{tabular}

When participants were asked if they can handle mistakes there were 35 responses. Of the participants, one $(100.00 \%)$ designated they were "poor" at handling mistakes and the FFA was "very influential." There were four $(100.00 \%)$ participants who rated FFA "average "replying FFA was "very influential." There were 21 participants who rated themselves as "good" at handling mistakes with two $(9.52 \%)$ indicating FFA was "not at all influential," six (28.57\%) responded FFA was "somewhat influential," and 13 (61.90\%) responded FFA being "very Influential. Of the nine participants who rated their ability to handle mistakes "excellent" one (11.11\%) responded FFA was "slightly influential," one (11.11\%) indicated FFA was "somewhat 
influential," two (22.22\%) replied FFA was "very influential," and five (55.56\%)

responded FFA was "extremely influential." None of the participants rated their ability to handle mistakes as "very poor." (see Table 40).

Table 40

Ability to Handle Mistakes and FFA's Influence

\begin{tabular}{lcccccccccc}
\hline & \multicolumn{2}{c}{ Very Poor } & \multicolumn{2}{c}{ Poor } & \multicolumn{2}{c}{ Average } & \multicolumn{2}{c}{ Good } & \multicolumn{2}{c}{ Excellent } \\
\cline { 2 - 10 } & $\mathrm{N}$ & $\%$ & $\mathrm{~N}$ & $\%$ & $\mathrm{~N}$ & $\%$ & $\mathrm{~N}$ & $\%$ & $\mathrm{~N}$ & $\%$ \\
\hline $\begin{array}{l}\text { Not at all } \\
\text { Influential }\end{array}$ & 0 & 0.00 & 0 & 0.00 & 0 & 0.00 & 2 & 9.52 & 0 & 0.00 \\
$\begin{array}{l}\text { Slightly } \\
\text { Influential }\end{array}$ & 0 & 0.00 & 0 & 0.00 & 0 & 0.00 & 0 & 0.00 & 1 & 11.11 \\
$\begin{array}{l}\text { Somewhat } \\
\text { Influential }\end{array}$ & 0 & 0.00 & 0 & 0.00 & 0 & 0.00 & 6 & 28.57 & 1 & 11.11 \\
$\begin{array}{l}\text { Very } \\
\text { Influential }\end{array}$ & 0 & 0.00 & 1 & 100.00 & 4 & 100.00 & 13 & 61.90 & 2 & 22.22 \\
$\begin{array}{l}\text { Extremely } \\
\text { Influential }\end{array}$ & 0 & 0.00 & 0 & 0.00 & 0 & 0.00 & 0 & 0.00 & 5 & 55.56 \\
\hline
\end{tabular}

Participants were asked if they can be tactful and what FFA's influence was. There were two (100.00\%) participants who rated their ability "average "indicating FFA was "somewhat influential.". There were 19 participants who rated themselves as "good" at being tactful with two (10.53\%) indicating FFA was "not at all influential," one (5.26\%) responding FFA was "slightly influential," two (10.53\%) responded FFA was "somewhat influential," 13 (68.42\%) responded FFA being "very influential," and one (5.26\%) responding FFA was "extremely influential." Of the 14 participants who rated their ability "excellent" three (21.43\%) designated FFA was "somewhat influential," four 
(28.57\%) indicated FFA was "very influential," and seven (50.00\%) specified FFA was "extremely influential." None of the participants rated their ability to be tactful as "very poor" or "poor" (see Table 41).

Table 41

Ability to be Tactful and FFA's Influence

\begin{tabular}{lcccccccccc}
\hline & \multicolumn{2}{c}{ Very Poor } & \multicolumn{2}{c}{ Poor } & \multicolumn{2}{c}{ Average } & \multicolumn{2}{c}{ Good } & \multicolumn{2}{c}{ Excellent } \\
\cline { 2 - 10 } & $\mathrm{N}$ & $\%$ & $\mathrm{~N}$ & $\%$ & $\mathrm{~N}$ & $\%$ & $\mathrm{~N}$ & $\%$ & $\mathrm{~N}$ & $\%$ \\
\hline $\begin{array}{l}\text { Not at all } \\
\text { Influential }\end{array}$ & 0 & 0.00 & 0 & 0.00 & 0 & 0.00 & 2 & 10.53 & 0 & 0.00 \\
$\begin{array}{l}\text { Slightly } \\
\text { Influential }\end{array}$ & 0 & 0.00 & 0 & 0.00 & 0 & 0.00 & 1 & 5.26 & 0 & 0.00 \\
$\begin{array}{l}\text { Somewhat } \\
\text { Influential }\end{array}$ & 0 & 0.00 & 0 & 0.00 & 2 & 100.00 & 2 & 10.53 & 3 & 21.43 \\
$\begin{array}{l}\text { Very } \\
\text { Influential }\end{array}$ & 0 & 0.00 & 0 & 0.00 & 0 & 0.00 & 13 & 68.42 & 4 & 28.57 \\
$\begin{array}{l}\text { Extremely } \\
\text { Influential }\end{array}$ & 0 & 0.00 & 0 & 0.00 & 0 & 0.00 & 1 & 5.26 & 7 & 50.00 \\
\hline
\end{tabular}

When respondents were asked if they can be flexible and at what was FFA's influence. There were five participants who rated their ability "average" with three $(60.00 \%)$ indicating FFA was "somewhat influential," and two (40.00\%) indicating FFA was "very influential." There were 21 participants who rated themselves as "good" at being flexible with one (4.76\%) indicating FFA was "not at all influential," three (14.29\%) indicating FFA was "slightly influential," three (14.29\%) responded FFA was "somewhat influential," $10(47.62 \%)$ responded FFA was "very influential," and four (19.05\%) responded FFA was "extremely influential." Of the nine participants who rated 
themselves "excellent" three (33.33\%) replied FFA was "somewhat influential," two $(22.22 \%)$ rated FFA "very influential," and four (44.44\%) indicated FFA was "extremely influential." None of the participants rated their flexibility as "very poor" or "poor" (see Table 42).

Table 42

Ability to be Flexible and FFA's Influence

\begin{tabular}{|c|c|c|c|c|c|c|c|c|c|c|}
\hline & \multicolumn{2}{|c|}{ Very Poor } & \multicolumn{2}{|c|}{ Poor } & \multicolumn{2}{|c|}{ Average } & \multicolumn{2}{|c|}{ Good } & \multicolumn{2}{|c|}{ Excellent } \\
\hline & $\mathrm{N}$ & $\%$ & $\mathrm{~N}$ & $\%$ & $\mathrm{~N}$ & $\%$ & $\mathrm{~N}$ & $\%$ & $\mathrm{~N}$ & $\%$ \\
\hline $\begin{array}{l}\text { Not at all } \\
\text { Influential }\end{array}$ & 0 & 0.00 & 0 & 0.00 & 0 & 0.00 & 1 & 4.76 & 0 & 0.00 \\
\hline $\begin{array}{l}\text { Slightly } \\
\text { Influential }\end{array}$ & 0 & 0.00 & 0 & 0.00 & 0 & 0.00 & 3 & 14.29 & 0 & 0.00 \\
\hline $\begin{array}{l}\text { Somewhat } \\
\text { Influential }\end{array}$ & 0 & 0.00 & 0 & 0.00 & 3 & 60.00 & 3 & 14.29 & 3 & 33.33 \\
\hline $\begin{array}{l}\text { Very } \\
\text { Influential }\end{array}$ & 0 & 0.00 & 0 & 0.00 & 2 & 40.00 & 10 & 47.62 & 2 & 22.22 \\
\hline $\begin{array}{l}\text { Extremely } \\
\text { Influential }\end{array}$ & 0 & 0.00 & 0 & 0.00 & 0 & 0.00 & 4 & 19.05 & 4 & 44.44 \\
\hline
\end{tabular}

Participants were asked what FFA's influence was on their ability to get along with other and how well they are able to get along with others. Of the 12 respondents who designated they were "good" at setting personal goals one $(8.33 \%)$ replied FFA was “slightly influential," three (25.00\%) specified FFA was "somewhat influential," six $(50.00 \%)$ responded FFA was "very influential," and two (16.67\%) responding FFA was “extremely influential." Of the respondents, 22 designated they were "excellent" at setting personal goals with three (13.64\%) indicating FFA was "somewhat influential," 
four (18.18\%) replying FFA was "very influential," and 15 (68.18\%) replying FFA was "extremely influential." None of the respondents specified they were "very poor," "poor," or "average" at getting along with others (see Table 43).

Table 43

Ability to Get Along with Others and FFA's Influence

\begin{tabular}{lcccccccccc}
\hline & \multicolumn{2}{c}{ Very Poor } & \multicolumn{2}{c}{ Poor } & \multicolumn{2}{c}{ Average } & \multicolumn{2}{c}{ Good } & \multicolumn{2}{c}{ Excellent } \\
\cline { 2 - 10 } & $\mathrm{N}$ & $\%$ & $\mathrm{~N}$ & $\%$ & $\mathrm{~N}$ & $\%$ & $\mathrm{~N}$ & $\%$ & $\mathrm{~N}$ & $\%$ \\
\hline $\begin{array}{l}\text { Not at all } \\
\text { Influential }\end{array}$ & 0 & 0.00 & 0 & 0.00 & 0 & 0.00 & 0 & 0.00 & 0 & 0.00 \\
$\begin{array}{l}\text { Slightly } \\
\text { Influential }\end{array}$ & 0 & 0.00 & 0 & 0.00 & 0 & 0.00 & 1 & 8.33 & 0 & 0.00 \\
$\begin{array}{l}\text { Somewhat } \\
\text { Influential }\end{array}$ & 0 & 0.00 & 0 & 0.00 & 0 & 0.00 & 3 & 25.00 & 3 & 13.64 \\
$\begin{array}{l}\text { Very } \\
\text { Influential }\end{array}$ & 0 & 0.00 & 0 & 0.00 & 0 & 0.00 & 6 & 50.00 & 4 & 18.18 \\
$\begin{array}{l}\text { Extremely } \\
\text { Influential }\end{array}$ & 0 & 0.00 & 0 & 0.00 & 0 & 0.00 & 2 & 16.67 & 15 & 68.18 \\
\hline
\end{tabular}

When respondents were asked if they could clarify their values, three $(100.00 \%)$ respondents reported they were "average" at determining values indicating FFA was "somewhat influential." Of the 15 respondents who replied they were "good" at setting personal goals two (13.33\%) indicated FFA was "slightly influential," two (13.33\%) responded FFA was "somewhat influential," and $11(73.33 \%)$ designated FFA was "very influential." Of respondents, 16 designated they were "excellent" at setting personal goals with one (6.25\%) indicating FFA was "slightly influential," three (18.75\%) indicating FFA was "somewhat influential," two (12.50\%) replying FFA was "very influential," and 
$10(62.50 \%)$ replying FFA was "extremely influential." No respondents replied they were "very poor" or "poor" at clarifying personal values (see Table 44).

Table 44

Ability to Clarify Personal Values and FFA's Influence

\begin{tabular}{lcccccccccc}
\hline & \multicolumn{2}{c}{ Very Poor } & \multicolumn{2}{c}{ Poor } & \multicolumn{2}{c}{ Average } & \multicolumn{2}{c}{ Good } & \multicolumn{2}{c}{ Excellent } \\
\cline { 2 - 10 } & $\mathrm{N}$ & $\%$ & $\mathrm{~N}$ & $\%$ & $\mathrm{~N}$ & $\%$ & $\mathrm{~N}$ & $\%$ & $\mathrm{~N}$ & $\%$ \\
\hline $\begin{array}{l}\text { Not at all } \\
\text { Influential }\end{array}$ & 0 & 0.00 & 0 & 0.00 & 0 & 0.00 & 0 & 0.00 & 0 & 0.00 \\
$\begin{array}{l}\text { Slightly } \\
\text { Influential }\end{array}$ & 0 & 0.00 & 0 & 0.00 & 0 & 0.00 & 2 & 13.33 & 1 & 6.25 \\
$\begin{array}{l}\text { Somewhat } \\
\text { Influential }\end{array}$ & 0 & 0.00 & 0 & 0.00 & 3 & 100.00 & 2 & 13.33 & 3 & 18.75 \\
$\begin{array}{l}\text { Very } \\
\text { Influential }\end{array}$ & 0 & 0.00 & 0 & 0.00 & 0 & 0.00 & 11 & 73.33 & 2 & 12.50 \\
$\begin{array}{l}\text { Extremely } \\
\text { Influential }\end{array}$ & 0 & 0.00 & 0 & 0.00 & 0 & 0.00 & 0 & 0.00 & 10 & 62.50 \\
\hline
\end{tabular}

When the participants were asked if they use rational thinking and what FFA's influence was, there was one (100.00\%) participants who rated their ability "average" responding FFA was "very influential." There were 15 participants who rated themselves as "good" at being flexible with one (6.67\%) responding FFA was "not at all influential," one (6.67\%) responding FFA was "slightly influential," six (40.00\%) responded FFA was "somewhat influential," six (40.00\%) responded FFA was "very influential," and one (6.67\%) specified FFA was "extremely influential." Of the 18 participants who rated themselves "excellent" one (5.56\%) replied FFA state presidency was "slightly influential," five (27.78\%) replied FFA was "somewhat influential," four (22.22\%) rated 
FFA “very influential," and eight (44.44\%) responded FFA was "extremely influential." None of the participants rated their ability to use rational thinking as "very poor" or “poor” (see Table 45).

Table 45

Ability to Use Rational Thinking and FFA's Influence

\begin{tabular}{lcccccccccc}
\hline & \multicolumn{2}{c}{ Very Poor } & \multicolumn{2}{c}{ Poor } & \multicolumn{2}{c}{ Average } & \multicolumn{2}{c}{ Good } & \multicolumn{2}{c}{ Excellent } \\
\cline { 2 - 10 } & $\mathrm{N}$ & $\%$ & $\mathrm{~N}$ & $\%$ & $\mathrm{~N}$ & $\%$ & $\mathrm{~N}$ & $\%$ & $\mathrm{~N}$ & $\%$ \\
\hline $\begin{array}{l}\text { Not at all } \\
\text { Influential }\end{array}$ & 0 & 0.00 & 0 & 0.00 & 0 & 0.00 & 1 & 6.67 & 0 & 0.00 \\
$\begin{array}{l}\text { Slightly } \\
\text { Influential }\end{array}$ & 0 & 0.00 & 0 & 0.00 & 0 & 0.00 & 1 & 6.67 & 1 & 5.56 \\
$\begin{array}{l}\text { Somewhat } \\
\text { Influential }\end{array}$ & 0 & 0.00 & 0 & 0.00 & 0 & 0.00 & 6 & 40.00 & 5 & 27.78 \\
$\begin{array}{l}\text { Very } \\
\text { Influential }\end{array}$ & 0 & 0.00 & 0 & 0.00 & 1 & 100.00 & 6 & 40.00 & 4 & 22.22 \\
$\begin{array}{l}\text { Extremely } \\
\text { Influential }\end{array}$ & 0 & 0.00 & 0 & 0.00 & 0 & 0.00 & 1 & 6.67 & 8 & 44.44 \\
\hline
\end{tabular}

Participants were asked if they show a responsible attitude and to what degree FFA influenced their ability. There were five who rated their ability "average" two $(40.00 \%)$ indicating FFA was "not at all influential," one $(20.00 \%)$ responding FFA was “slightly influential," one (20.00\%) indicating FFA was “somewhat influential," and one (20.00\%) replying FFA was "very influential." There were 18 participants who rated FFA "good" two (11.11\%) indicated FFA was "slightly influential," seven (38.89\%) calling is “somewhat influential," seven (38.89\%) responding FFA was "very influential," and two (11.11\%) replying FFA was "extremely influential." Of the 11 participants who rated 
FFA “excellent” one (9.09\%) responded FFA was "slightly influential." Four $(36.36 \%)$ replied FFA was “very influential," and six (54.55\%) designated FFA was “extremely influential." None of the participants rated their ability to be open to change "very poor" or "poor" (see Table 46).

Table 46

Open to Change and FFA's Influence

\begin{tabular}{|c|c|c|c|c|c|c|c|c|c|c|}
\hline & \multicolumn{2}{|c|}{ Very Poor } & \multicolumn{2}{|c|}{ Poor } & \multicolumn{2}{|c|}{ Average } & \multicolumn{2}{|c|}{ Good } & \multicolumn{2}{|c|}{ Excellent } \\
\hline & $\mathrm{N}$ & $\%$ & $\mathrm{~N}$ & $\%$ & $\mathrm{~N}$ & $\%$ & $\mathrm{~N}$ & $\%$ & $\mathrm{~N}$ & $\%$ \\
\hline $\begin{array}{l}\text { Not at all } \\
\text { Influential }\end{array}$ & 0 & 0.00 & 0 & 0.00 & 2 & 40.00 & 0 & 0.00 & 0 & 0.00 \\
\hline $\begin{array}{l}\text { Slightly } \\
\text { Influential }\end{array}$ & 0 & 0.00 & 0 & 0.00 & 1 & 20.00 & 2 & 11.11 & 1 & 9.09 \\
\hline $\begin{array}{l}\text { Somewhat } \\
\text { Influential }\end{array}$ & 0 & 0.00 & 0 & 0.00 & 1 & 20.00 & 7 & 38.89 & 0 & 0.00 \\
\hline $\begin{array}{l}\text { Very } \\
\text { Influential }\end{array}$ & 0 & 0.00 & 0 & 0.00 & 1 & 20.00 & 7 & 38.89 & 4 & 36.36 \\
\hline $\begin{array}{l}\text { Extremely } \\
\text { Influential }\end{array}$ & 0 & 0.00 & 0 & 0.00 & 0 & 0.00 & 2 & 11.11 & 6 & 54.55 \\
\hline
\end{tabular}

Respondents were asked if they have good manners and to what degree FFA influenced them. There were 14 respondents who rated their possession of good manners “good," one (7.14\%) calling FFA "slightly influential," three (21.43\%) indicating FFA was "somewhat influential," six (42.86\%) replying FFA was "very influential," and four (28.57\%) indicating FFA was “extremely influential.” Of the 21 respondents who rated their ability "excellent" three (14.29\%) specified FFA was "slightly influential," three (14.29\%) replied FFA was "somewhat influential," one (4.76\%) responded FFA was 
"very influential," and 14 (66.67\%) indicated FFA was “extremely influential." None of respondents rated their manners as "very poor," "poor," or "average" (see Table 47).

Table 47

Possess Good Manners and FFA's Influence

\begin{tabular}{lcccccccccc}
\hline & \multicolumn{2}{c}{ Very Poor } & \multicolumn{2}{c}{ Poor } & \multicolumn{2}{c}{ Average } & \multicolumn{2}{c}{ Good } & \multicolumn{2}{c}{ Excellent } \\
\cline { 2 - 10 } & $\mathrm{N}$ & $\%$ & $\mathrm{~N}$ & $\%$ & $\mathrm{~N}$ & $\%$ & $\mathrm{~N}$ & $\%$ & $\mathrm{~N}$ & $\%$ \\
\hline $\begin{array}{l}\text { Not at all } \\
\text { Influential }\end{array}$ & 0 & 0.00 & 0 & 0.00 & 0 & 0.00 & 0 & 0.00 & 0 & 0.00 \\
$\begin{array}{l}\text { Slightly } \\
\text { Influential }\end{array}$ & 0 & 0.00 & 0 & 0.00 & 0 & 0.00 & 1 & 7.14 & 3 & 14.29 \\
$\begin{array}{l}\text { Somewhat } \\
\text { Influential }\end{array}$ & 0 & 0.00 & 0 & 0.00 & 0 & 0.00 & 3 & 21.43 & 3 & 14.29 \\
$\begin{array}{l}\text { Very } \\
\text { Influential }\end{array}$ & 0 & 0.00 & 0 & 0.00 & 0 & 0.00 & 6 & 42.86 & 1 & 4.76 \\
$\begin{array}{l}\text { Extremely } \\
\text { Influential }\end{array}$ & 0 & 0.00 & 0 & 0.00 & 0 & 0.00 & 4 & 28.57 & 14 & 66.67 \\
\hline
\end{tabular}

Participants were asked if they trust other people and how much FFA influenced their ability to trust others. There were eight participants who answered they had an "average" trust in other people, one (12.50\%) who designated FFA was "slightly influential," four (50.00\%) stated FFA as "somewhat influential," and three (37.50\%) who rated FFA "very influential." There were 17 participants who rated their ability "good," one (5.88\%) replied FFA was "not at all influential," one (5.88\%) calling is "slightly influential," six (35.29\%) responded FFA was "somewhat influential," and nine (52.94\%) indicating FFA was "very influential." Of the seven participants who rated their ability "excellent" one (14.29\%) indicated FFA was "somewhat influential," and six 
(85.71\%) specified FFA was "extremely influential." None of the participants rated their positive self-concept as "very poor" or "poor" (see Table 48).

Table 48

Ability to Trust Other People and FFA's Influence

\begin{tabular}{lcccccccccc}
\hline & \multicolumn{1}{c}{ Very Poor } & \multicolumn{2}{c}{ Poor } & \multicolumn{2}{c}{ Average } & \multicolumn{2}{c}{ Good } & \multicolumn{2}{c}{ Excellent } \\
\cline { 2 - 10 } & $\mathrm{N}$ & $\%$ & $\mathrm{~N}$ & $\%$ & $\mathrm{~N}$ & $\%$ & $\mathrm{~N}$ & $\%$ & $\mathrm{~N}$ & $\%$ \\
\hline $\begin{array}{l}\text { Not at all } \\
\text { Influential }\end{array}$ & 0 & 0.00 & 0 & 0.00 & 0 & 0.00 & 1 & 5.88 & 0 & 0.00 \\
$\begin{array}{l}\text { Slightly } \\
\text { Influential }\end{array}$ & 0 & 0.00 & 0 & 0.00 & 1 & 12.50 & 1 & 5.88 & 0 & 0.00 \\
$\begin{array}{l}\text { Somewhat } \\
\text { Influential }\end{array}$ & 0 & 0.00 & 0 & 0.00 & 4 & 50.00 & 6 & 35.29 & 1 & 14.29 \\
$\begin{array}{l}\text { Very } \\
\text { Influential }\end{array}$ & 0 & 0.00 & 0 & 0.00 & 3 & 37.50 & 9 & 52.94 & 0 & 0.00 \\
$\begin{array}{l}\text { Extremely } \\
\text { Influential }\end{array}$ & 0 & 0.00 & 0 & 0.00 & 0 & 0.00 & 0 & 0.00 & 6 & 85.71 \\
\hline
\end{tabular}

When respondents were asked if they are able to lead a team and what FFA's influence was, two (100.00\%) respondents responded they were "average" at leading a team and FFA was "very influential." Of the 12 respondents who indicated they were "good" at leading a team two (16.67\%) replied FFA "somewhat influential," six (50.00\%) designated FFA was "very influential," and four (33.33\%) indicating FFA was "extremely influential." Of respondents, 20 indicated they were "excellent" at leading a team with two $(10.00 \%)$ responding FFA was “somewhat influential," five (25.00\%) replying FFA was "very influential," and 13 (65.00\%) indicating FFA was "extremely 
influential." None of the respondents replied they were "very poor" or "poor" at leading a team (see Table 49).

Table 49

Ability to Lead a Team and FFA's Influence

\begin{tabular}{lcccccccccc}
\hline & \multicolumn{2}{c}{ Very Poor } & \multicolumn{2}{c}{ Poor } & \multicolumn{2}{c}{ Average } & \multicolumn{2}{c}{ Good } & \multicolumn{2}{c}{ Excellent } \\
\cline { 2 - 10 } & $\mathrm{N}$ & $\%$ & $\mathrm{~N}$ & $\%$ & $\mathrm{~N}$ & $\%$ & $\mathrm{~N}$ & $\%$ & $\mathrm{~N}$ & $\%$ \\
\hline $\begin{array}{l}\text { Not at all } \\
\text { Influential }\end{array}$ & 0 & 0.00 & 0 & 0.00 & 0 & 0.00 & 0 & 0.00 & 0 & 0.00 \\
$\begin{array}{l}\text { Slightly } \\
\text { Influential }\end{array}$ & 0 & 0.00 & 0 & 0.00 & 0 & 0.00 & 0 & 0.00 & 0 & 0.00 \\
$\begin{array}{l}\text { Somewhat } \\
\text { Influential }\end{array}$ & 0 & 0.00 & 0 & 0.00 & 0 & 0.00 & 2 & 16.67 & 2 & 10.00 \\
$\begin{array}{l}\text { Very } \\
\text { Influential }\end{array}$ & 0 & 0.00 & 0 & 0.00 & 2 & 100.00 & 6 & 50.00 & 5 & 25.00 \\
$\begin{array}{l}\text { Extremely } \\
\text { Influential }\end{array}$ & 0 & 0.00 & 0 & 0.00 & 0 & 0.00 & 4 & 33.33 & 13 & 65.00 \\
\hline
\end{tabular}

Respondents were asked if they are able to follow guidelines and to what degree FFA influenced their ability. There were 15 respondents who rated their ability "good," four $(26.67 \%)$ calling FFA “somewhat influential," 10 (66.67\%) replying FFA was "very influential," and one (6.67\%) indicating FFA was "extremely influential." Of the 19 respondents who rated FFA "excellent" one (5.26\%) responded FFA was "not at all influential," four (21.05\%) replied FFA was “somewhat influential," three (15.79\%) designated FFA was "very influential," and 11 (57.89\%) responded FFA was "Extremely Influential. None of the respondents rated their ability to follow guidelines as "very poor," "poor," or "average" (see Table 50). 
Table 50

Ability to Follow Guidelines and FFA's Influence

\begin{tabular}{|c|c|c|c|c|c|c|c|c|c|c|}
\hline & \multicolumn{2}{|c|}{ Very Poor } & \multicolumn{2}{|c|}{ Poor } & \multicolumn{2}{|c|}{ Average } & \multicolumn{2}{|c|}{ Good } & \multicolumn{2}{|c|}{ Excellent } \\
\hline & $\mathrm{N}$ & $\%$ & $\mathrm{~N}$ & $\%$ & $\mathrm{~N}$ & $\%$ & $\mathrm{~N}$ & $\%$ & $\mathrm{~N}$ & $\%$ \\
\hline $\begin{array}{l}\text { Not at all } \\
\text { Influential }\end{array}$ & 0 & 0.00 & 0 & 0.00 & 0 & 0.00 & 0 & 0.00 & 1 & 5.26 \\
\hline $\begin{array}{l}\text { Slightly } \\
\text { Influential }\end{array}$ & 0 & 0.00 & 0 & 0.00 & 0 & 0.00 & 0 & 0.00 & 0 & 0.00 \\
\hline $\begin{array}{l}\text { Somewhat } \\
\text { Influential }\end{array}$ & 0 & 0.00 & 0 & 0.00 & 0 & 0.00 & 4 & 26.67 & 4 & 21.05 \\
\hline $\begin{array}{l}\text { Very } \\
\text { Influential }\end{array}$ & 0 & 0.00 & 0 & 0.00 & 0 & 0.00 & 10 & 66.67 & 3 & 15.79 \\
\hline $\begin{array}{l}\text { Extremely } \\
\text { Influential }\end{array}$ & 0 & 0.00 & 0 & 0.00 & 0 & 0.00 & 1 & 6.67 & 11 & 57.89 \\
\hline
\end{tabular}




\section{CHAPTER V}

\section{Conclusions/Recommendations/Implications}

\section{Purpose of the Study}

The purpose of this study was to determine if the past West Virginia State FFA Presidents and their current career and personal success had any relation to their training

during their state presidency. To determine whether the leadership skills they developed through FFA carried over into future endeavors and whether their service to a youth organization resulted in them becoming a leader or volunteer in youth or community organizations later.

\section{Objectives of the Study}

The objectives of the study are reflected in the following research questions:

1. What impact did FFA, and more specifically being a WV FFA State President, have on past state presidents' careers?

2. How active are past state presidents in organizations related to agriculture, as well as organizations unrelated to agriculture, including offices held?

3. What impact did FFA have on current leadership abilities?

4. Are past FFA state presidents still active with FFA at the local, state, or national level (volunteering or as alumni members)?

\section{Summary}

The study found that most people perceived their leadership abilities were good or excellent with being a West Virginia FFA State President to have been very to extremely influential. The majority of the individuals were male with their ages ranging from 41-60. Most of the individuals had taken an entrepreneurship SAE and lived on a farm during 
their FFA career. The study also found that the majority of the individuals currently live on a farm or in a rural area not on a farm. Most of the respondents had held a chapter office of President, Vice President, Secretary, or a combination thereof. All participants received their high school diploma and 30 out of 35 received a four-year degree. The study also found that initial professional careers were almost evenly split as to whether they were agriculturally related with the highest percentage of individuals in the education and training sector. While the highest percentage of current or at retirement professional careers were in the education and training sector, there were a larger number of careers that were not agriculturally related. Initial careers and careers at retirement included various type of positions: teachers, farmer, attorneys, pastors, veterinarians, etc. When looking at the career fields, there were a steady number of individuals in the following areas: education and training, agriculture, marketing, and STEM (science, technology, engineering, and mathematics). The areas of human services, business management, and finance showed an increase in number of individuals in that career field from initial career to current, while the career fields of hospitality, health science, transportation, law and security, and government saw a decrease in the number of individuals involved.

With regard to current involvement the study found that less than half of those surveyed were active in any of the six areas at the chapter level and that the percentage of involvement decreased at the regional-district, state, and national levels. It was found that the largest percentage of respondents participated in three specific contest areas at the chapter level or higher: creed (91.43\%), parliamentary procedure (94.29\%), and prepared public speaking $(61.43 \%)$. 
American FFA/ American Farmer Degrees were received by a majority of the respondents and most of the respondents held another state office other than presidency. The survey found that $50 \%$ or more of the respondents had participated in the following activities outside of FFA: church groups (96.97\%), 4-H (72.41\%), club officer for other clubs (67.74\%), clubs other than FFA (63.33\%), class officer (59.37\%), student council (57.58\%), and fraternity/ sorority (50\%).

In almost all of the leadership ability categories, a majority of the respondents rated their ability as excellent reporting that FFA was very or extremely influential. A majority of the participants rated themselves as good at being able to delegate responsibility with the second most reporting they were excellent. Of the ones who rated themselves as good, most indicated that FFA was very influential. One respondent rated themselves as poor at delegating responsibility and said that FFA was somewhat influential.

When considering input from others, the majority rated themselves as good and the remainder rated themselves as excellent. The participants who rated themselves as good, 15 out of the 22 said FFA was very influential. When considering the ability to handle mistakes, most of the participants said they were good at handling mistakes, with a majority saying FFA was very influential. However, one respondent indicated they were very poor at handling mistakes and FFA was very influential.

When reviewing the open comments from participants, most agreed that FFA was a main factor in their future success crediting God, family, friends, and mentors/ advisors with their continued growth and success in life. 


\section{Recommendations}

The following recommendations are based upon the findings of this study.

1. Alumni Associations need to look at what it would take to recruit more past West Virginia FFA state presidents into local, state, and the national chapters.

2. State and National FFA Associations need to focus on the value of training State FFA Presidents as it pertains to their future careers and personal goals.

3. Current involvement shows that less than half of past West Virginia FFA State Presidents are involved in FFA at a chapter, regional/district, state, or national level. This lack of involvement from individuals who rated their leadership skills so high and how FFA had impacted their leadership abilities should be further studied as why they are not more involved.

4. State associations need to consider current training and how it will influence State FFA Presidents in their future career and personal lives. This training should be viewed as important not only to the immediate work of the state president but also for their community and future FFA endeavors after their FFA membership.

5. Chapter FFA Advisors need to consider long term career and personal benefits of running for state office and the influence being a state officer has on their members. There should also be a more in-depth look at chapter participation and how it affects members running for office. 


\section{Recommendations for Further Studies}

1. Further studies need to be conducted on the remainder of past West Virginia state officers not surveyed in this research to develop a closer look at what success they have had and what influence(s) the FFA experience had on them.

2. More research is needed to define the relationships that exist between life skills learned as a result of participation as a West Virginia State FFA President, and those that are used in jobs and careers.

3. Current officer training needs to be evaluated to look at whether officers are able to gain the experience necessary for future careers.

4. This study should be replicated in other states to see how responses compare.

5. A future study looking into exactly what influenced past state officer in leadership abilities. Taking a look at other factors in their lives and how much those areas influenced them: family, friends, careers, college, other organizations, etc.

6. Further studies need to look at years since being an active member and participation in the organization and the correlation between years out of FFA and inactivity.

7. A further comparison of age, perception of leadership abilities, and FFA's influence needs to be compared to find any relationships.

8. Further study needs to look closer at the leadership abilities and whether the influence FFA had on their ability was positive or negative. 


\section{REFERENCES}

Adedokun, O. A., \& Balshweid, M. A. (2009). Investigating community factors as predictors of rural 11th-grade agricultural science students' choice of careers in agriculture. Journal of Agriculture Education, 49(4), 1-10.

Ary, D., Jacobs, L. C., \& Razavieh, A. (2002). Introduction to research in education. Belmont, CA: Wadsworth/Thomson Learning.

Brannon, T. L., Holley, C. W., \& Key, J. P. (1989). Impact of vocational agriculture/ FFA on Community Leadership. The Journal of Agriculture Education, 30(3), 3745.

Hoover, T. S., Scholl, J. F., Dunigan, A. H., \& Mamontova, N. (2007). A Historical Review of Leadership Development in the FFA and 4-H. Journal of Agricultural Education, 48(3), 100-110.

National FFA Organization. (2015). FFA mission and motto. Retrieved from National FFA Organization Web Site: https://www.ffa.org/about/who-we-are/missionmotto

National FFA Organization. (2015). FFA official manual. Retrieved from National FFA Organization:

https://www.ffa.org/sitecollectiondocuments/ffa_official_manual_english.pdf

Reese, S. (2011). Creating the leaders of tomorrow today. Techniques: Connecting Education and Careers (J1), 86(5), 16-21.

Ricketts, J. C., \& Rudd, R. D. (2004). Leadership development factors leading to the success of former Florida State. Journal of Southern Agricultural Education Research, 54(1), 242-253.

Robinson, J.P., Shaver, P.R., \& Wrightsman, L.S. (1991). Criteria for scale selection and evaluation. In J.P. Robinson, P.R. Shaver, \& L.S. Wrightsman (Eds.). Measures of personality and social psychological attitudes (pp. 1-16). New York: Academic Press.

Sims, L. J. (2014). Motivational factors contributing to the choice of agriculturally related careers. (Unpublished Master's thesis). West Virginia University, Morgantown, WV.

Staller, B. (2001). Teachers as moves managers. FFA Advisors Making a Difference, 9 (7), 13.

Talbert, B. A., \& Balschweid, M. A. (2006). Career aspirations of selected FFA members. Journal of Agriculture Education, 47(2), 67-80. 
Wingenbach, G. J. (1995). Self-perceived youth leadership and life skills development among Iowa FFA members. Retrospective Theses and Dissertations. Paper 11022. Retrieved from http://lib.dr.iastate.edu/rtd/11022 
APPENDICES 
APPENDIX A:

Cover Letter 
Dear Past West Virginia FFA State Presidents,

As a Past West Virginia FFA State Presidents you are a vital part of understanding the benefits that come along with being an FFA state officer. Your past experience as a state president will help us to better understand how being a state FFA officer can influence someone's career and personal life.

I am Jada Bennett, a graduate student in Agricultural and Extension Education; and under the direction of my advisor, Dr. Deborah Boone, we are conducting a survey to determine the influence that being a State FFA President has on individuals and their career and personal life. The results of this study will be used to prepare a thesis to partially fulfill the requirements for a Masters in Agricultural and Extension Education.

We are surveying past West Virginia FFA State Officer who were elected between the years of 1955-2005. The results will provide insight to many groups of people including chapter advisors on why to encourage students to be a state officer, as well as State Advisors on how to recruit and what benefits can be gained from being a state Please take a few moments and share your opinions and experiences with us.

Participation in this research study is completely voluntary and all information you provide will be held as confidential as possible. The survey should only take about twenty minutes to complete, and your response to the survey is crucial to the success of the study. You may skip any question you are not comfortable answering and you can stop at any time. You will notice a code number at the top left of the return envelope. This code will be used to identify non-respondents for follow-up and will be destroyed before the data are analyzed. Survey results will be reported in a summary format and individual responses will not be identified.

The Institutional Review Board (IRB) at West Virginia University has approved this study. If you have any questions or concerns about completing the questionnaire or about being in this study, you may contact me at jhostut4@mix.wvu.edu or 304-8392367.

Place the completed questionnaire in the enclosed postage-paid self- addressed return envelope and drop it in the mail. Please return your completed questionnaire before October 14, 2015. Thank you in advance for your assistance with this research effort. We sincerely appreciate your participation.

Sincerely,

Jada Bennett

Deborah Boone

Master Student

Professor

Agricultural and Extension Education 
APPENDIX: B

Questionnaire 


\section{Impact of being a West Virginia State FFA President on Career and Personal Accomplishments as Perceived by Past State FFA State Presidents 1955 and 2005}

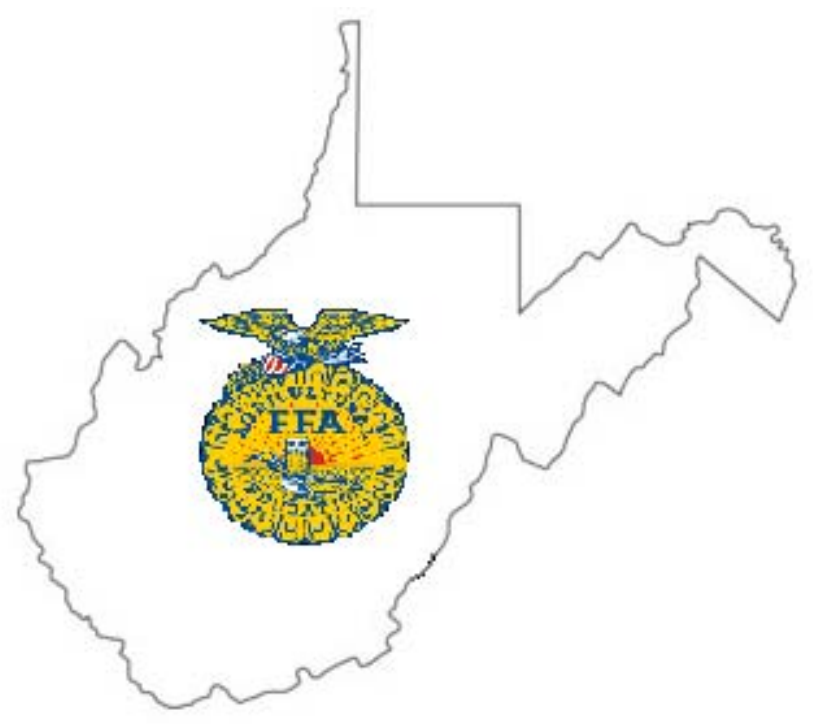

Jada M. Bennett

Graduate Student

Agricultural and Extension Education

Davis College of Agriculture, Natural Resource, and Design

West Virginia University

Morgantown, WV 26506 


\section{SAE and FFA Experience}

Instructions: Please answer the following questions to the best of your ability. Please mark all that apply for each question. If your answer is "other" provide a brief description or response

1. Which area(s) were represented by your Supervised Agriculture Experience/ Supervised Farming Program/ Supervised Opportunity Employment Program? (Check all that apply)
A. Entrepreneurship
B. Placement
C. Research Exploratory
D. School Based Enterprise
E. Service- Learning
F. Home Improvement

2. What was the relationship between your Supervised Agriculture Experience/ Supervised Farming Program/ Supervised Opportunity Employment Program and your initial and current professional job(s). (Check one in each row)

\begin{tabular}{|l|l|l|l|l|}
\hline & $\begin{array}{l}\text { Strong } \\
\text { Relationship }\end{array}$ & $\begin{array}{l}\text { Average } \\
\text { relationship }\end{array}$ & $\begin{array}{l}\text { Some } \\
\text { relationship }\end{array}$ & $\begin{array}{l}\text { No } \\
\text { relationship }\end{array}$ \\
\hline A. Initial professional job & & & & \\
\hline $\begin{array}{l}\text { B. Current (or at retirement) } \\
\text { professional job }\end{array}$ & & & & \\
\hline
\end{tabular}

4. In what areas did you compete while an FFA member? Please indicate if you competed at the chapter, regional/district, state, and/or national level. (Check all that apply)

\begin{tabular}{|l|l|l|l|l|}
\hline \multicolumn{1}{|c|}{ Area of competition } & Chapter & $\begin{array}{c}\text { Regional/ } \\
\text { district }\end{array}$ & State & National \\
\hline Creed Speaking & & & & \\
\hline Agriscience Fair & & & & \\
\hline Agricultural Communications & & & & \\
\hline Agricultural Issues Forum & & & & \\
\hline Extemporaneous Public Speaking & & & & \\
\hline Job Interview & & & & \\
\hline Parliamentary Procedure & & & & \\
\hline Prepared Public Speaking & & & & \\
\hline Career Development Events & & & & \\
\hline $\begin{array}{l}\text { Other Competitions (please } \\
\text { specify__ }\end{array}$ & & & & \\
\hline
\end{tabular}


5. What offices did you hold at the chapter level? (check all that apply)

A. President

B. Vice President

C. Secretary

D. Treasurer

E. Reporter

F. Sentinel

G. Historian

H. Parliamentarian

I. Chaplain

J. Assistant/Junior President

K. Assistant/Junior Vice President

L. Assistant/Junior Secretary

M. Assistant/Junior Treasurer

N. Assistant/Junior Reporter

O. Assistant/Junior Sentinel

P. Assistant/Junior Historian

Q. Assistant/Junior Parliamentarian

R. Assistant/Junior Chaplain

6. How many FFA members were in your home chapter the year you were elected to a state officer?
A. $1-30$
B. $31-60$
C. $61-90$
D. $91-120$
E. $121-150$
F. $151-180$
G. 181 and over

7. Did you receive your American FFA/American Farmer Degree?
A. Yes
B. No 
8. Did you run for National FFA Office?

A. Yes

B. No

9. Did you serve as a state officer other than State President?

A. Yes

B. No 


\section{Involvement}

Instructions: How did your involvement in FFA leadership activities compare to the leadership opportunities you receive from participating in other school or community activities? Please use the scale below to indicate your level of comparison for leadership skills between FFA and the activities listed. (Please consider the activities from the time you entered FFA until the time you aged out.)

\begin{tabular}{|c|c|c|c|c|c|c|}
\hline & 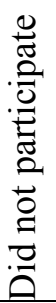 & $\begin{array}{l}\overline{\bar{D}} \\
\bar{\Xi} \\
\sum_{\bar{z}}^{ \pm}\end{array}$ & $\begin{array}{l}\dot{\Xi} \\
\stackrel{0}{0} \\
0 \\
0 \\
0 \\
0\end{array}$ & 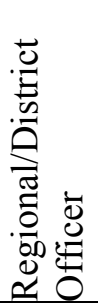 & 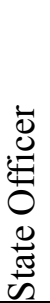 & 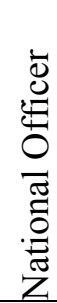 \\
\hline \multicolumn{7}{|l|}{ High School Activities } \\
\hline 10. Student Council & 0 & 1 & 2 & 3 & 4 & 5 \\
\hline 11. Class Officer & 0 & 1 & 2 & 3 & 4 & 5 \\
\hline 12. Club Officer & 0 & 1 & 2 & 3 & 4 & 5 \\
\hline 13. Drama & 0 & 1 & 2 & 3 & 4 & 5 \\
\hline 14. Band & 0 & 1 & 2 & 3 & 4 & 5 \\
\hline 15. TSA & 0 & 1 & 2 & 3 & 4 & 5 \\
\hline 16. Sports & 0 & 1 & 2 & 3 & 4 & 5 \\
\hline 17. FHA/FCCLA & 0 & 1 & 2 & 3 & 4 & 5 \\
\hline 18. DECA & 0 & 1 & 2 & 3 & 4 & 5 \\
\hline 19. VICA & 0 & 1 & 2 & 3 & 4 & 5 \\
\hline 20. FBLA & 0 & 1 & 2 & 3 & 4 & 5 \\
\hline 21. SkillsUSA & 0 & 1 & 2 & 3 & 4 & 5 \\
\hline \multicolumn{7}{|l|}{ Community Activities } \\
\hline 22. Church Groups & 0 & 1 & 2 & 3 & 4 & 5 \\
\hline 23. Scouts & 0 & 1 & 2 & 3 & 4 & 5 \\
\hline 24. Junior Achievement & 0 & 1 & 2 & 3 & 4 & 5 \\
\hline 25. JTPA & 0 & 1 & 2 & 3 & 4 & 5 \\
\hline 26. $4-\mathrm{H}$ & 0 & 1 & 2 & 3 & 4 & 5 \\
\hline 27. After School, Summer, or College Job & 0 & 1 & 2 & 3 & 4 & 5 \\
\hline 28. Pageant & 0 & 1 & 2 & 3 & 4 & 5 \\
\hline 29. Other: & 0 & 1 & 2 & 3 & 4 & 5 \\
\hline
\end{tabular}




\begin{tabular}{|c|c|c|c|c|c|c|}
\hline & 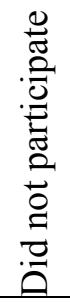 & $\begin{array}{l}\overline{\mathrm{d}} \\
\bar{E} \\
\sum^{2}\end{array}$ & 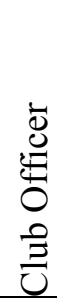 & 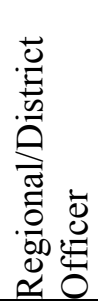 & 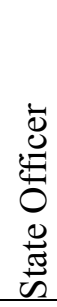 & 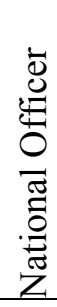 \\
\hline \multicolumn{7}{|l|}{ College Activities } \\
\hline 30. University Student Council & 0 & 1 & 2 & 3 & 4 & 5 \\
\hline 31. College Student Council & 0 & 1 & 2 & 3 & 4 & 5 \\
\hline 32. Club Involvement & 0 & 1 & 2 & 3 & 4 & 5 \\
\hline 33. Sports & 0 & 1 & 2 & 3 & 4 & 5 \\
\hline 34. Fraternity/ Sorority & 0 & 1 & 2 & 3 & 4 & 5 \\
\hline 35. Band & 0 & 1 & 2 & 3 & 4 & 5 \\
\hline 36. Other Clubs & 0 & 1 & 2 & 3 & 4 & 5 \\
\hline
\end{tabular}




\section{Leadership Skills}

Instructions: For the following statements please indicate on the left hand side how you perceive your current ability on each item, on the right hand side of the table indicate how influential being State FFA President was on the development of that skill.

\begin{tabular}{|c|c|c|c|c|c|c|c|c|c|c|}
\hline \multirow[b]{2}{*}{ Leadership Skills: } & \multicolumn{5}{|c|}{ Perception of Current Abilities } & \multicolumn{5}{|c|}{$\begin{array}{c}\text { Influence of Being State President on } \\
\text { Current Ability }\end{array}$} \\
\hline & 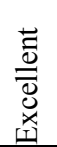 & $\begin{array}{l}\text { ¿ } \\
8 \\
0\end{array}$ & 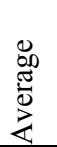 & 。ँ & $\begin{array}{l}\dot{0} \\
0 \\
2 \\
2 \\
2\end{array}$ & 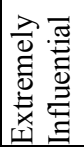 & : & 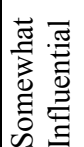 & 㺃 & 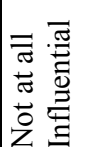 \\
\hline $\begin{array}{l}\text { 37. Can determine personal } \\
\text { needs }\end{array}$ & 5 & 4 & 3 & 2 & 1 & 5 & 4 & 3 & 2 & 1 \\
\hline $\begin{array}{l}\text { 38. Can determine group } \\
\text { needs }\end{array}$ & 5 & 4 & 3 & 2 & 1 & 5 & 4 & 3 & 2 & 1 \\
\hline $\begin{array}{l}\text { 39. Have a positive self- } \\
\text { concept }\end{array}$ & 5 & 4 & 3 & 2 & 1 & 5 & 4 & 3 & 2 & 1 \\
\hline 40. Can express feelings & 5 & 4 & 3 & 2 & 1 & 5 & 4 & 3 & 2 & 1 \\
\hline 41. Can set personal goals & 5 & 4 & 3 & 2 & 1 & 5 & 4 & 3 & 2 & 1 \\
\hline 42. Can set group goals & 5 & 4 & 3 & 2 & 1 & 5 & 4 & 3 & 2 & 1 \\
\hline $\begin{array}{l}\text { 43. Can be honest with } \\
\text { others }\end{array}$ & 5 & 4 & 3 & 2 & 1 & 5 & 4 & 3 & 2 & 1 \\
\hline $\begin{array}{l}\text { 44. Can use information to } \\
\text { solve problems }\end{array}$ & 5 & 4 & 3 & 2 & 1 & 5 & 4 & 3 & 2 & 1 \\
\hline $\begin{array}{l}\text { 45. Can delegate } \\
\text { responsibility }\end{array}$ & 5 & 4 & 3 & 2 & 1 & 5 & 4 & 3 & 2 & 1 \\
\hline 46. Can set priorities & 5 & 4 & 3 & 2 & 1 & 5 & 4 & 3 & 2 & 1 \\
\hline 47. Am sensitive to others & 5 & 4 & 3 & 2 & 1 & 5 & 4 & 3 & 2 & 1 \\
\hline 48. Am open minded & 5 & 4 & 3 & 2 & 1 & 5 & 4 & 3 & 2 & 1 \\
\hline $\begin{array}{l}\text { 49. Consider the needs of } \\
\text { others }\end{array}$ & 5 & 4 & 3 & 2 & 1 & 5 & 4 & 3 & 2 & 1 \\
\hline $\begin{array}{l}\text { 50. Show a responsible } \\
\text { attitude }\end{array}$ & 5 & 4 & 3 & 2 & 1 & 5 & 4 & 3 & 2 & 1 \\
\hline $\begin{array}{l}\text { 51. Have a friendly } \\
\text { personality }\end{array}$ & 5 & 4 & 3 & 2 & 1 & 5 & 4 & 3 & 2 & 1 \\
\hline $\begin{array}{l}\text { 52. Consider input from all } \\
\text { group members }\end{array}$ & 5 & 4 & 3 & 2 & 1 & 5 & 4 & 3 & 2 & 1 \\
\hline 53. Can listen effectively & 5 & 4 & 3 & 2 & 1 & 5 & 4 & 3 & 2 & 1 \\
\hline 54. Can select alternatives & 5 & 4 & 3 & 2 & 1 & 5 & 4 & 3 & 2 & 1 \\
\hline 55. Respect others & 5 & 4 & 3 & 2 & 1 & 5 & 4 & 3 & 2 & 1 \\
\hline
\end{tabular}




\begin{tabular}{|c|c|c|c|c|c|c|c|c|c|c|}
\hline \multirow[b]{2}{*}{ Leadership Skills: } & \multicolumn{5}{|c|}{ Perception of Current Abilities } & \multicolumn{5}{|c|}{$\begin{array}{c}\text { Influence of Being State President on } \\
\text { Current Ability }\end{array}$} \\
\hline & 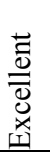 & $\begin{array}{l}0 \\
8 \\
5\end{array}$ & 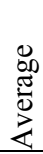 & $\begin{array}{l}\dot{0} \\
.\end{array}$ & $\begin{array}{l}\dot{0} \\
0 \\
2 \\
2 \\
2 \\
2\end{array}$ & 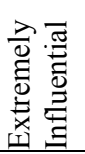 & 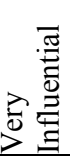 & 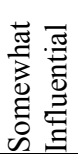 & 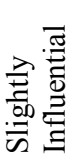 & 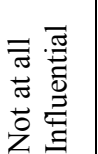 \\
\hline 56. Can solve problem & 5 & 4 & 3 & 2 & 1 & 5 & 4 & 3 & 2 & 1 \\
\hline 57. Can handle mistakes & 5 & 4 & 3 & 2 & 1 & 5 & 4 & 3 & 2 & 1 \\
\hline 58. Can be tactful & 5 & 4 & 3 & 2 & 1 & 5 & 4 & 3 & 2 & 1 \\
\hline 59. Can be flexible & 5 & 4 & 3 & 2 & 1 & 5 & 4 & 3 & 2 & 1 \\
\hline 60. Get along with others & 5 & 4 & 3 & 2 & 1 & 5 & 4 & 3 & 2 & 1 \\
\hline 61. Can clarify my values & 5 & 4 & 3 & 2 & 1 & 5 & 4 & 3 & 2 & 1 \\
\hline 62. Use rational thinking & 5 & 4 & 3 & 2 & 1 & 5 & 4 & 3 & 2 & 1 \\
\hline 63. Am open to change & 5 & 4 & 3 & 2 & 1 & 5 & 4 & 3 & 2 & 1 \\
\hline 64. Have good manners & 5 & 4 & 3 & 2 & 1 & 5 & 4 & 3 & 2 & 1 \\
\hline 65. Trust other people & 5 & 4 & 3 & 2 & 1 & 5 & 4 & 3 & 2 & 1 \\
\hline 66. Am able to lead a team & 5 & 4 & 3 & 2 & 1 & 5 & 4 & 3 & 2 & 1 \\
\hline $\begin{array}{l}\text { 67. Am able to follow } \\
\text { guidelines }\end{array}$ & 5 & 4 & 3 & 2 & 1 & 5 & 4 & 3 & 2 & 1 \\
\hline
\end{tabular}




\section{Demographics}

68. What is your gender?
A. Male
B. Female

69. How would you describe your "Current Place of Residence?" (Check one)
A. Farm
B. Rural non-farm
C. Town or city $10,000-49,999$
D. Suburb or city over 50,000

70. How would you describe your "Place of Residence" during your FFA years? (Check one)
A. Farm
B. Rural non-farm
C. Town or city $10,000-49,999$
D. Suburb or city over 50,000

71. What is your employment status? (Check one)

A. Full-time off-farm employment - no farming

B. Part-time off-farm employment - no farming

C. Full-time off-farm employment - part-time farming

D. Full time farmer - part time off-farm employment

E. Full time farmer - full time off-farm employment

F. Full time farmer no outside employment

G. Part time farmer with part time off-farm employment

H. Retired and part time farmer

I. Retired and full time farmer

J. Retired

70. What was your initial professional job? ( Please list job title and employer)

71. What is your current/occupation (or at retirement)? (Please list job title and employer) 
72. What is your age? (Check one)

A. 30 years and below

B. $31-40$ years

C. $41-50$ years

D. $51-60$ years

E. $\quad 61-70$ years

F. Over 70 years

73. Please check all degrees and certifications you have received and provide information on each degree/certification. (Check all that apply and list)

A. Did not graduate high school

B. High School diploma or equivalent

C. Some college. Major:

D. Technical Certification. Certification:

E. Two - year college degree. Degree:

F. Four - year college degree. Degree:

G. Graduate degree (Master's) Degree:

H. .Graduate degree $(\mathrm{PhD})$ : Degree:

I. Professional degree. Degree:

74. Using the following categories, please indicate your level of involvement with the FFA. Indicate if the involvement was at the Chapter, Regional/district, State, and/or National levels. (check all that apply)

\begin{tabular}{|l|l|l|l|l|}
\hline & Chapter & $\begin{array}{l}\text { Regional/ } \\
\text { District }\end{array}$ & State & National \\
\hline Honorary member & & & & \\
\hline Alumni/ Booster member & & & & \\
\hline Fundraiser supporter & & & & \\
\hline Team coach/ mentor & & & & \\
\hline Monetary supporter & & & & \\
\hline Volunteer & & & & \\
\hline
\end{tabular}


Instructions: What leadership roles have you held since aging out of FFA? Please list the organization, role, years holding that role, did your State officer training help with these roles (yes or no)?

\begin{tabular}{|c|c|c|c|}
\hline Organization & Role & $\begin{array}{l}\text { Years holding } \\
\text { that role }\end{array}$ & $\begin{array}{c}\text { Did state officer training } \\
\text { help you? }\end{array}$ \\
\hline 75. & & & $\ldots$ Yes $\_$No \\
\hline 76. & & & Yes _ No \\
\hline 77. & & & Yes $\ldots$ No \\
\hline 78. & & & Yes $\quad$ No \\
\hline 79. & & & $\ldots$ Yes __ No \\
\hline 80. & & & Yes \\
\hline 81. & & & Yes \\
\hline 82. & & & Yes _ـ No \\
\hline 83. & & & $\ldots$ Yes $\_$No \\
\hline 84. & & & Yes No \\
\hline
\end{tabular}

Comments (regarding questionnaire): 


\section{Thank you for taking the time to complete this questionnaire!}

If you have any questions regarding the questionnaire, please contact me or my advisor at:

Jada Bennett: jhostut4@mix.wvu.edu

Dr. Deborah Boone: debby.boone@mail.wvu.edu

Phone: (304) 293-5450

P.O. Box 6108

Morgantown, WV 26506 
APPENDIX C:

Responses to Initial Professional Career 


\section{RESPONSES TO INITIAL PROFESSIONAL CAREER}

- Activity Director

- Administration and Operation Chief

- $\quad$ Ag Teacher(9)

- Attorney(2)

- Consultant

- County Extension Agent

- $\mathrm{CPA}$

- Dairy Herdsman

- Engineer

- Insurance Sales(2)

- Officer, Colonel

- Part Owner Operator(2)

- Pastor

- Police Officer

- Purchasing Agent

- School Bus Driver

- Self-employed

- Soil Scientist

- Speech-Language Pathologist

- Truck Driver

- Veterinarian (3)

- $\mathrm{x}$-ray technologist 


\section{APPENDIX D:}

\section{Responses to Current or at Retirement Professional Career}




\section{RESPONSES TO CURRENT OR AT RETIREMENT CAREER}

- Ag Ed Coordinator(2)

- Ag teacher(2)

- Attorney(2)

- Board of Education Member

- Branch Manager Engineer

- County Operation Trainee

- CPA

- Extension Leaders

- Financial Services

- Generator Specialist

- Heavy Equipment Operator

- Lead Pastor

- Manager

- Owner(2)

- $\operatorname{Pastor}(2)$

- Phys Ed teacher

- Professor of Biology and Animal Veterinary Science-

- Realtor

- Rural Mail Carrier

- Sales Manager

- School Administrator(2)

- Special Education Teacher 
- Speech Language Pathologist

- Stay at home mother

- Sustainable Agriculture consultant and managing director

- Veterinarian(2) 
APPENDIX E:

Responses to Organizations Holding Leadership Roles 


\section{RESPONSES TO ORGANIZATIONS HOLDING LEADERSHIP ROLES}

- $4-\mathrm{H}(2)$

- Ag Teachers Association

- $\quad$ AIB School(2)

- $\mathrm{ASCE}$

- (County) Board of Education

- Chamber of Commerce

- Charleston Chapter WVSCPA(3)

- Chi-Epsilon

- $\operatorname{Church}(19)$

- City Government(2)

- CLCC Board of Directors

- College/ University

- College of Arts and Science

- Community Water Board

- County ACT

- County Farm Bureau(3)

- County Government

- $\mathrm{CSO}$

- Direct Enrollment Marketing

- Elks

- $\quad$ ETE Space Net

- Faculty Senate 
- Fair Board(6)

- Fairfield Glade

- Farm Environment

- Farm Museum

- FFA Alumni(3)

- Genesis Healthcare

- Golden Key National Council

- Grocery Store

- House of Delegates

- IAVAT(2)

- International Telecomp Association Inc

- JCJRIMR

- JOCC Director

- Landcare

- Lions

- LKAC Ath. Conference

- Local Community Association

- Local School(15)

- Masons

- MC Bow Club

- Mental Health

- MOMS Club

- National Federation of High School 
- National Sheep Shearer Association

- National Tractor Pullers Association Inc

- OVACAT Conference

- Political Committee

- Professional Org

- Real Estate

- Rotary(5)

- Soil Conservation Society America

- Sun Healthcare

- Susan G Komen WV Affiliate

- Military(2)

- (University) Dairy Team

- (County) Soil and Water District

- WV ACT Board Division

- WV FFA(2)

- WVAAE(4)

- WVACTE

- (University) Administration

- (University) Honors College

- Young Farmer(2) 
APPENDIX F:

Other Comments 


\section{Open Comments}

The following comments were recorded directly from the instruments and no edits were made for grammatical and/or spelling errors.

- I expect that as a younger person, I would have viewed the FFA State

Presidency as having had more of an effect. Many other activities have had an opportunity to impact my life. It was an interesting exercise.

- Anxious to see survey results! Interesting to think about the changes in FFA since term as state president i.e. new contests and/or activities. Best wishes!

- Any success I have had as a teacher, Principal, or Board of Education member I owe to an excellent VoAg teacher and the FFA. I remain a supporter.

- FFA was a great experience at the chapter and State level. It helped me build confidence, improve my public speaking, learn parliamentary procedure, and enjoy the influence of teachers and state employees who helped me immensely

- I hope this helps. FFA was a huge help to me. Before FFA I had no selfconfidence. God used the program to change my life! I'm glad to do the survey for you, now please do something for me: get your Bible and please look at Romans 3:23, Romans 6:23, and Romans 10:9-10

- I know that being state 2 nd vice president and state president was a very great move in my career. I was blessed by all the invaluable learning that the FFA gave me. I have received many honors and served 4 rural county seat for 32 years and gave leadership in Mental Health, Library Board, Building Commission, Public Service District, Conference Board of Missions, etc. 
- I was fortunate to have had great parents and family also my vo-ag teacher was the best Bond Bible; He started my education and training in FFA and Agriculture before I started the seventh grade at UHS. He taught me how to win and do my best- I won two judging contests my first year in Vo-Ag. Along with my father and mother. Mr. Bible showed me many things that I have never forgotten- we were able to win at all levels. The Future Farmers of America has given me more than I have been able to give back. I will always hold the WV FFA Association at the highest level for learning and growing for any young person. It is there if you apply yourself.

- I'm glad to see this type of research on the positive impact the FFA provides. I never fail to credit this outstanding organization with a major role in whatever degree of success I have enjoyed.

- In section 2 the chart and the questions to respond do not match up to me. Section 3 I feel many of the abilities are what led me to be a state officer in the first place. Your questions leads to being an officer developed that skill. At least to me anyway.

- My experience as a state FFA president helped me earn many scholarships to qualify and continue my college education. My husband and I were able to purchase a farm and now build our own home because of my experience as a state officer. The Farm Service Agency highly regards the WV State FFA Association and knew that I would be a responsible owner because of it. I will be replacing the current Special Education Coordinator at our school upon her 
retirement, and this is because of so much I learned while being involved with the state FFA.

- Obviously objectivity is your goal. However, subjective experimental reality. I believe is greater than that which objective questions might reveal. Besides my relationship with God, my spouse, and my parents(family), no other organization or partnership for that what the FFA is fundamentally about, has influenced my life as much as having my few years in this fellowship of farmers. Not even my years with the united State Marine Corps. Now, today I'm still learning from my time in this leadership oriented organization. As i from time to time reflect on my many and varied experiences from those five years. I observe how the values I learned are directing me even today. In addition, and maybe foremost, the Chapter Advisor(s) are the most important people in this organization. Their character will either build up or tear down. And for the State Officer, that State Advisor and Executive Director are so very vital. Leadership be gets leadership. Apart from solid character based leadership, this partnership as I referred to the FFA earlier will build something other than that which we long to experience from our your people.

- Some of the questions were ambiguous- not clear how to answer (75). 71 should have asked if off-farm employment was ag-related. Question 6- It was a long time ago. I don't recall specifically and the categories had pretty narrow ranges. My response might not be accurate. Nice job. Good luck! I hope you send everyone an abstract of your findings.

- Success to you! 
- Training is valuable but the experience you receive is much more valuable in developing character that extends into adult life settings. I had these life shaping experiences that enabled me to draw on during my entire life. I won the National Junior Sheep Shearing contest in 1960 at the Indiana State Fair. Setting time records that stood up for 8 years. A larger shearing machine with a 2.5 head helped my record fall. Served as State President the year I was elected as National Vice President. The National FFA Constitution was amended 3 years later to prevent a member running for National Office while serving as state officer. The National Officer experience has been the prime leadership experience of my life. In 1963-1964 selected as a 4-H IFYE to spend 6 months in India. This experience rounded my development as a leader. 
VITA

Education:

WEST VIRGINIA UNIVERSITY, Morgantown, WV 26506

Master of Science in Agricultural and Extension

Education.

Graduated May 2016

SHEPHERD UNIVERSITY, Shepherdstown, WV 25443

Bachelor of Science in Business Administration

Graduated in December 2013

Professional

4-H Program Assistant, West Virginia University Extension Experience: Service-Mineral County

State President, West Virginia FFA Association 